Jarmo Seppälä

\title{
Development of Student-centred Language Learning Environment
}

Metropolia University of Applied Sciences

Bachelor of Engineering

Media Technology

Bachelor's thesis

3 April 2017 


\begin{tabular}{|c|c|}
\hline $\begin{array}{l}\text { Author } \\
\text { Title } \\
\text { Number of Pages } \\
\text { Date }\end{array}$ & $\begin{array}{l}\text { Jarmo Seppälä } \\
\text { Development of Student-centred Language Learning } \\
\text { Environment } \\
58 \text { pages } \\
3 \text { April } 2017\end{array}$ \\
\hline Degree & Bachelor of Engineering \\
\hline Degree Programme & Media Technology \\
\hline Specialization option & Digital Media \\
\hline Instructors & $\begin{array}{l}\text { Kuniaki Yajima, Professor } \\
\text { Ilkka Kylmäniemi, Lecturer }\end{array}$ \\
\hline \multirow{3}{*}{\multicolumn{2}{|c|}{$\begin{array}{l}\text { The purpose of this study was to develop a web-based language learning platform for Sendai } \\
\text { National College of Technology. The application is aimed for the exchange students of the } \\
\text { aforementioned school and is meant to facilitate students' language learning and to endorse } \\
\text { a self-driven way of learning. The operating logic and data handling of the application were } \\
\text { implemented by using the AngularJS framework and the Firebase data storage platform. In } \\
\text { addition to this, HTML5 techniques and JavaScript-based plugins were used to create visu- } \\
\text { ally different views and various transitions. } \\
\text { Student-centred learning is considered one of the most significant pedagogical point of } \\
\text { views. Active student participation and connecting learning processes to real world situations } \\
\text { are one of the defining properties of the approach. A student-centred learning environment } \\
\text { offers students the tools for content production and management with interactive and com- } \\
\text { munal elements, altogether producing a personalized learning experience. Participatory and } \\
\text { socially connected Web, or "Web } 2.0 \text { " has brought elements of social media and open con- } \\
\text { tent into the field of learning, enabling the evolvement of student-centred web-based learn- } \\
\text { ing platforms. This trend is often referred as e-learning } 2.0 \text {. } \\
\text { Sendai colleges are renewing their pedagogical models by implementing student-centred } \\
\text { methods to teaching and classroom activities. The need for renewal also gave rise to the } \\
\text { subject for this thesis work. Development of the application started in November } 2016 \text {. } \\
\text { The application is still in development, but its current features fulfill the initial objects set to } \\
\text { it in the design process, with good qualifications for further development. In its current form, } \\
\text { the application provides a collaborative and student-centred environment, the features of } \\
\text { which complement the pedagogical models that are appropriate to modern mobile services. }\end{array}$}} \\
\hline & \\
\hline & \\
\hline Keywords & $\begin{array}{l}\text { learning, student-centred learning, Web 2.0, CALL, AngularJS, } \\
\text { rebase }\end{array}$ \\
\hline
\end{tabular}




\begin{tabular}{|c|c|}
\hline $\begin{array}{l}\text { Tekijä } \\
\text { Otsikko } \\
\text { Sivumäärä } \\
\text { Aika }\end{array}$ & $\begin{array}{l}\text { Jarmo Seppälä } \\
\text { Oppijakeskeinen verkko-oppimisjärjestelmä kielen opiskeluun } \\
58 \text { sivua } \\
3.4 .2017\end{array}$ \\
\hline Tutkinto & Insinööri (AMK) \\
\hline Koulutusohjelma & Mediatekniikka \\
\hline Suuntautumisvaihtoehto & Digitaalinen media \\
\hline Ohjaajat & $\begin{array}{l}\text { Professori Kuniaki Yajima } \\
\text { Lehtori Ilkka Kylmäniemi }\end{array}$ \\
\hline \multirow{3}{*}{\multicolumn{2}{|c|}{$\begin{array}{l}\text { Insinöörityön tarkoituksena oli kehittää kielen opiskeluun verkko-oppimisjärjestelmä, joka tu- } \\
\text { lee Sendain teknisen korkeakoulun vaihto-opiskelijoiden käyttöön. Järjestelmän tarkoitus on } \\
\text { helpottaa opiskelijoiden kielen opiskelua tarjoamalla verkko-oppimisympäristö, jossa opis- } \\
\text { kelijat ovat aktiivisia tiedon rakentajia ja jossa oppimisen lopputuloksiin pyritään yhteistoi- } \\
\text { minnan ja opiskelijoiden henkilökohtaisten käsitysten ja assosiaatioiden kautta. Järjestel- } \\
\text { män toimintalogiikka ja tiedonhallinta toteutettiin verkkopohjaisia AngularJS- ja Firebase- } \\
\text { ohjelmistokehyksiä ja -alustoja käyttäen. Tämän lisäksi eri näkymien visuaaliseen toteutuk- } \\
\text { seen käytettiin HTML5-tekniikoita ja JavaScriptiin perustuvia lisäosia. } \\
\text { Nykyään merkittävänä oppimisteoreettisena näkökulmana pidetään oppijakeskeisyyttä, } \\
\text { jossa korostuu muun muassa oppijan aktiivinen toiminta oppimisprosessissa ja näiden pro- } \\
\text { sessien liittäminen oikean elämän tilanteisiin. Oppijakeskeinen ympäristö tarjoaa työkaluja } \\
\text { sisällön tuotantoon ja hallintaan sekä vuorovaikutusta ja yhteisöllisyyttä. Tietotekniikassa } \\
\text { sosiaalinen media ja vapaat sisällöt ovat mahdollistaneet tämänkaltaisten verkko-oppi- } \\
\text { misalustojen kehityksen. Tätä kehityssuuntaa verkko-oppimisalustoissa kutsutaan e-lear- } \\
\text { ning 2.0:ksi. } \\
\text { Sendain teknisessä korkeakoulussa on pyritty viime vuosina uudistamaan opetustyyliä ra- } \\
\text { kentamalla sitä oppijakeskeisyyttä tukevan pedagogiikan ympärille. Koulun uudistumistarve } \\
\text { opetuksessa myös nosti esille tämän opinnäytetyön aiheen. Järjestelmän kehitystyö aloitet- } \\
\text { tiin marraskuussa 2016. } \\
\text { Järjestelmän kehitys on vielä kesken, mutta se täyttää jo nykyisillä toiminnoillaan alussa } \\
\text { asetettuja tavoitteita ja luo hyvän perustan jatkokehitykselle. Sillä on myös nykymuodossaan } \\
\text { edellytyksiä tarjota vuorovaikutteinen ja oppijakeskeinen työympäristö, jonka toiminnollisuu- } \\
\text { det tukevat niitä pedagogisia malleja, jotka ovat nykyaikaisille verkko- ja mobiilisovelluksille } \\
\text { ominaisia. }\end{array}$}} \\
\hline & \\
\hline & \\
\hline Avainsanat & $\begin{array}{l}\text { verkko-oppiminen, oppijakeskeisyys, Web 2.0, CALL, } \\
\text { AngularJS, Firebase }\end{array}$ \\
\hline
\end{tabular}




\section{Table of contents}

Abbreviations

1 Introduction 1

2 Student-centred learning 3

2.1 Definition 3

2.2 Benefits 4

2.3 Use of e-learning platforms 5

2.4 Computer assisted language learning 8

$\begin{array}{ll}2.5 \text { Challenges in student-centred environments } & 10\end{array}$

3 Trends in web-based learning 13

$\begin{array}{lll}3.1 & \text { Technological and social advancements } & 13\end{array}$

$\begin{array}{ll}3.2 & \text { Platform agnostic web } \\ 3\end{array}$

3.3 Web 2.0 and language learning 16

$\begin{array}{ll}3.4 & 19\end{array}$

3.5 Existing platforms for language learning 20

4 Designing the application 23

4.1 Different paradigms to consider 23

4.2 Towards the application 25

4.3 Main features of the application 26

4.4 Importance of usability 29

5 Technical execution 32

5.1 Architecture 32

5.2 AngularJS 33

5.3 Data structures and bindings 35

$\begin{array}{lll}5.4 & \text { User interface implementation } & 38\end{array}$ 
6 Using the application 43

6.1 Profile configuration 43

6.2 Workflow of content creation 44

6.3 Analysis of the application 50

$\begin{array}{lll}6.4 & \text { Future prospects } & 50\end{array}$

7 Conclusion $\quad 52$

$\begin{array}{ll}\text { References } & 54\end{array}$ 


\section{Abbreviations}

SRS Spaced repetition system. Memorization and learning technique which utilizes timed intervals.

MVC Model-View-Controller. Architectural model used in software development.

SPA Single page application. Web application that loads content to only one page, providing a similar user experience to mobile applications.

JSON JavaScript object notation. File format for open source information distribution across platforms.

API Application programming interface. Set of definitions according to which different programs can interact and exchange information with each other.

DOM Document object model. Way to describe an HTML structure as a tree made of objects.

AJAX Asynchronous JavaScript and XML. Programming technique which allows information retrieval from external services.

REST Architectural model for implementing application programming interfaces. 


\section{Introduction}

This thesis examines the development of a web-based language learning environment which is aimed for the use of exchange students arriving in Sendai National College of Technology, Japan. The purpose of this thesis is to develop a language learning environment, where the students are actively contributing to the learning process and where the learning outcomes are achieved through an individual's own conceptions and associations. The thesis also examines the theory of student-centred learning on a general level and the growing trends of e-learning with a focus on language learning, while keeping the student-centred perspective in alignment.

Student-centred learning is considered a significant perspective among learning theories and many higher educations are already practicing the approach. Active student participation in the learning process and connecting them to real life situations are one of the core properties of a student-centred learning environment. Student-centred learning is an effective method in higher education and the approach also suits Internet-based learning or e-learning well. Information and communication technology has become an integrated part of learning as well as teaching, especially in language teaching. Technology savvy teachers can combine e-learning as a part of their curricula to enhance learning and teaching situations. Easily accessible materials, time and place independent studying and immediate feedback facilitate the students' learning process.

In the last few years Sendai National College of Technology has been incorporating student-centred methods in the school's pedagogy. The urge for transformation has also spawned new project ideas, and thus, plans for an application enhancing exchange students' Japanese language studies were established. The application is not meant to replace the classroom teaching, but to complement it by implementing some student-centred attributes to encourage collaboration and self-studying. The application is meant to be a complementary tool for language learning, so previous knowledge of the Japanese language is required.

While the traditional e-learning methods, such as structured course formats and tutorial videos, are still holding their appeal as a way of learning on the web, social media and open content have brought new opportunities to the field. E-learning is evolving into more student-centred direction, where the platforms offer more personalized and nonlinear 
learning experiences, social integration and a hands-on approach. Flexibility and crossplatform capability of modern web technologies have also spurred e-learning in mobile devices in a form of various mobile applications. This provides an opportunity for informal learning, as language learning occurs outside of official tuitions as well. This thesis approaches the trend of e-learning applications through the perspective of web development, as it keeps making major advancements consistently in cross-platform application development.

The architecture of the application developed for the SNCT is designed with AngularJS, which is a front-end programming framework, offering a modular base for developing modern web applications. Data handling and storage is handled by Firebase, which is an event-driven real-time database. In addition to this, HTML5 techniques and different JavaScript-based plugins were used to create visually different views and various transitions. Later chapters of this thesis explains the functionalities and views on both system and user interface level. 


\section{Student-centred learning}

\subsection{Definition}

During the past ten years, higher education has been witnessing new pedagogical approaches in teaching and learning. Growing trends include a transition from lecture oriented learning to a model where the focus of instruction is switched to the students. This type of pedagogy is generally referred to as student-centred learning, but using the term can have wide implications. The term may refer to the educational mindsets or instruction methods that recognize the dissimilarity of individual students and their specific learning needs. This said, student-centred learning can be comprised as an umbrella term, which encompasses a variety of potential instructional strategies and learning activities. Student-centred learning is broadly related to constructivist theory of learning in which learning is seen as an active process, where students construct their own knowledge based on previously known information and reflection. Information does not transfer to students - the students construct the information themselves. Student-centred learning is also supported by various other intersecting pedagogies, such as active learning, self-directed learning and cooperative learning and inquiry-based learning. Information technology is deeply linked to modern student-centred learning. [1.]

Student-centred learning remains a debated concept, as many interpretations between educators coexist and sometimes rule out one another. Despite of the different point of views, advocates of the concept usually highlight more or less the same characteristics that makes a learning environment student-centred. Among many researchers and experts, Jonassen, Lehtinen, Salomon and Ruokamo have discussed learner-centric theories in the context of web-based learning [2, 3]. By investigating the classifications established by the aforementioned researchers, common features can be found. Principles of a student-centred classroom includes the following four attributes.

- $\quad$ Construction of learning. Teacher can create situations that allows students to make connections to new ideas and shape new information through their initial abilities and sentiments with previously known, existing information.

- $\quad$ Authentic learning. Learning activities should be relatable and relevant for the students. Activities tied to real world context, for example through a meaningful project-work, promotes student motivation. Inquiry-based learning encourages students to ask their own questions, collect data and generate research hypotheses. [3, 299.] 
- $\quad$ Collaborative learning. It highlights the learning process, which occurs during interaction with other students. Students can take part in giving feedback, as well as in directing and supporting processes. Besides just students, contributing parties can consist of teachers or supervisors, with whom the information is being constructed.

- Goal-oriented learning. Students are aware of their own learning objectives and goals. Students are active in processes, where they have the responsibility. Metacognitive skills also promote learning and self-direction. Reflectivity also relates to goal-orientation, as it is based on understanding and being aware of one's own learning and internal habits. [2, 3-6.]

It is important to remember that this is just one definition of student-centred learning. The concept has existed for a long time and similar types of findings have been made by other groups and associations as well. One of the learning theorists, psychologist Carl Rogers, described that the student-centred approach is based on a hypothesis that students who are granted the freedom to explore and study the areas of their interests and who are accompanied by a supportive facilitator, not only achieve higher academic results, but also mature in the process, while taking personal values, such as flexibility and self-confidence into account. [4.]

\subsection{Benefits}

Properly implemented student-centred learning can offer benefits to the institution, students and teaching staff, higher education unions and in a wider scale, society as a whole. It aims to provide skills for life, create self-sufficient learners and respond to the changing needs of different individuals.

Benefits for the students come in various ways. Student-centred learning can encourage more in-depth learning and motivation, as students retain more of the information they learn when the element of active learning and participation is present. When students take responsibility for their own learning, they increase the potential of raising their curiosity to solve real-world problems. This independence enables students to gain other skills more effectively, such as teamwork, communication and task prioritization. A teacher acting as a facilitator and encouraging students to think for themselves, critical thinking and analytical skills are accumulated from early on. This enables two-sided discussions and exchange between teachers and students. Cooperation and valuing stu- 
dent opinions can further increase the engagement of students and can lead to participation in research projects and developing course structures. Benefits for students can also include becoming a part of the academic community more easily. [5, 3-5.]

Teachers can enjoy the benefits of student-centred learning as well, but these benefits might show in different ways. As the teacher's role is shifted towards a more facilitative direction, it offers an opportunity to academically challenge students in new ways, especially by using information technology. Given the opportunity for learning to be conducted in a multitude of ways, student-centred learning can have a positive impact on working conditions as it can reduce the negative aspects associated with teaching. Constructive feedback from the students enable teachers to review and develop their course structures and teaching methods, which can contribute to the teachers' continuous self-improvement. Student-centred learning can offer a high level of professional development in terms of development of new skills and competences. Technology savvy teachers are flexible in designing new ways of running a course or a programme component. [5, 6-9.]

Institutions and representative organizations of the teaching staff and students are also beneficial from any increases in general quality of students' academic experience and teachers' working conditions. On institutional level, these benefits can include better retention rates in higher education. This may be due to the flexible nature of student-centred courses and also due to higher student engagement in their studies. Learning within a student-centred learning environment makes students feel more valued, since their learning needs are the priority. In an environment where student needs are the essential part of learning experiences, teaching can be seen as being of higher of quality. An institution applying this approach can be more attractive to the potential students. Attaining mobility into the region where the institution is found also benefits the development of society. [5, 10-11.]

\subsection{Use of e-learning platforms}

Student-centred principles determine the methods for using programs and practices that provide education. Effectiveness of technology is defined by how it affects the complex interplay of these principles in education. Therefore, it is important to understand the nature of e-learning from a student-centred perspective [6]. 
Rosenberg defines e-learning as the "use of Internet technologies to deliver solutions that enhance knowledge and performance". Moreover, Rosenberg highlights that elearning is a network that allows instant revisions and distributions and is based on standardized Internet technology; distribution happens by using standard compliant technologies, so the user only needs to be connected to the Internet. Lastly, Rosenberg states that e-learning solutions are not limited to traditional models of teaching [7, 28]. Rosenberg's definition of e-learning largely supports the student-centred principles compiled from the findings of Jonassen and others. Various types of e-learning platforms have indeed consolidated their position in modern pedagogy, as they can provide tools for implementing these principles [2, 7-9].

E-learning environments have also impacted many education stakeholders. According to a tracking survey conducted by Allen and Seaman, total of 5.8 million higher education students in the United States enrolled to at least one e-learning course offered by a degree-granting institution during fall 2014. E-learning environments have altered the opinions of chief academic officers in higher education, as majority of them stated that learning outcomes in online education are nowadays "as good as or superior to face-to-face instruction" and agree that e-learning is "critical to the long-term strategies of their institutions" [8]. Online learning can meet the needs of different students, as it can help students who require additional help in their studies, while offering opportunities for high performing students to enroll to more advanced and challenging courses. E-learning can benefit organizations economically, as more students enroll to virtual courses. Fulfilling the school's mandate, e-learning can also be beneficial in a political sense. This results educating more students, including those with difficulties in completing the courses with a predetermined schedule. [3, 338-339.]

E-learning content is traditionally managed and distributed by using learning management systems (LMS) or learning content management systems (LCMS), which are similar kinds of e-learning platforms with different ideologies and purposes of use. LMS platforms are large application environments, which are typically aimed for university and enterprise use. A basic LMS platform includes such properties as enrolling to courses, monitoring learning progress and organizing tests, as well granting the students an access to course materials and an opportunity to be in contact with the instructor. Moodle is an example of an LMS platform. Quintessentially, an LMS platform is a learning dissemination tool, with an emphasis on distance learning. 
An LCMS provides a more complex platform for personalized content development, creating and management, with less emphasis on managing the experience of learners. It is a system designed to create and manage teaching materials for distance and classroom-based learning. The content of an LCMS platform are comprised of learning objects, which are smaller collections of different learning contents. Learning objects are relatively autonomous ensembles, which makes them versatile and reusable, as they can be used in different parts of the learning process $[9,57]$. The ideology behind LCMS platforms is specifically based on reusable learning contents and easy creation. [10.]

E-learning platforms in pedagogy still end up following relatively linear approaches in learning and teaching, which disregard creativity, collaboration and interaction between students. LMS platforms often give the image that learning is based on just going through courses. Course-oriented learning is usually based on formal learning and the idea that learning is a passive activity does not support student-centred ideology. The key problem in LMS platforms such as Moodle is that they are closed, top-to-bottom systems regulated by institutions. Students are rarely offered individual spaces, where personal learning could be managed. According Salasvuo, the prevailing consensus about LMS platforms is that they only very weakly support student-centred pedagogies [10]. Shore describes Moodle as an extension of the information exported by the teacher in the classroom, therefore making it a teacher-centred system, despite of having qualifications that encourage student-centred learning, such as discussion boards, tests and surveys [24]. New types of learning needs, such as mobile-based learning, are adding into the development of LMS platforms. Personalized learning environments (PLE) are often subjects of discourse. [11.]

Besides just technical management issues, there are other challenges incorporated with e-learning as well. One of the risks is related to human working memory, which is used to process new information. The capacity of working memory is limited and can become overloaded if used excessively - this is referred as cognitive overload. Contextual or action required information is temporally stored in human working memory from where it does not transfer to long-term memory. An e-learning platform containing a difficult navigation system, non-relevant elements, such as decorative pictures or animations that require additional mental processing, contribute to cognitive overload, which leaves minimal room for actual learning. Attention should also be paid to the e-learning content in itself, since the complexity and different task types can have an effect on cognitive load $[12,1183]$. For example, content requiring a lot reading can negatively affect students 
struggling with reading comprehension. Lack of teacher support and feedback can also cause some students to feel isolated or unconfident, which consequently leads to poor language learning performance [13].

\subsection{Computer assisted language learning}

Over the past decades, e-learning methods for language instruction have become an issue of interest for language learning and teaching, since the emergence of interactive, participatory and socially connected web, or "Web 2.0". The wealth of information available on the web offers an access to diverse language learning resources, for example through online journals and newspapers [13]. When incorporating information technologies in language learning, it is not uncommon to find different types of theories and acronyms established by different groups of practitioners, with each party representing their own views and philosophies. One of the most common terms is computer-assisted language learning or CALL, which describes the search and study of applying computer (or nowadays any IT-device) in language learning and teaching [14]. Within the scope of this thesis, language learning incorporating information technology is explicitly referred as CALL.

CALL has been present for many years and has gone through different typologies, which can be characterized as behaviorist, communicative and integrative CALL. These phases of CALL equate to a certain level of technology and pedagogical theories at a given time. Early adaptations of CALL were initially leaning towards behaviorism and systematic repetition, or "drill and practice". Very basic use can incorporate quizzes, flashcards and basic answer-response methods, where the computer is acting as a primitive tutor. $[15,911$.

CALL has since widened its scope to more communicative approaches, thus supporting ideologies of constructivism. The nature of the modern web in particular has expanded the power of CALL. The current philosophy of CALL puts emphasis on student-centred materials, leaning towards principles of integrative CALL. New approaches seek to integrate several language related skills, such as speaking, listening, reading and writing as well as technology into the process of language learning more thoroughly. Integrative methods encourage students to use technological utensils as a continuous process of language learning and to discover the most suitable learning paths for them. The teacher 
can take the role of a director by helping students to find and use complementary CALL materials and resources, or act as a manager of computer-mediated interaction among students inside and outside of class [14]. Drills and similar repetitive tasks still have a place in language learning, especially in the initial phases of vocabulary acquisition. Providing the same information in various modes, for example in audio, visual and textual content, enhances recognition and recall. [15, 911.]

According to a study conducted in the Middle East Technical University, CALL has been proven to be an effective tool in language learning and promoting learner autonomy in acquiring English as a second language. The results of the study suggest that the students got better in improving their language learning strategies, were highly motivated and with the aid of CALL, were willing to take responsibility for individual learning outside of the formal tuitions [16]. Although many studies suggest that CALL is an effective method, evaluating the influence on the quality of language learning itself is difficult. This is due to the complexity of interacting variables involved in setting the environment for teaching and learning languages, especially non-English languages. Some researches argue that CALL has not stabilized its place in language learning, because it has not gone through the normalization process of technology - a stage of becoming invisible and embedded in everyday practice. According to Bax, there is still an element of fear and exaggerated expectations surrounding CALL [17]. In turn, Hassan classifies the issues of CALL normalization into five categories:

- $\quad$ Personal issues. Success or failure mostly depends on the users; prohibiting factors can be lack of time, support and resources for the use of CALL.

- $\quad$ Technical issues. Premises aimed for language learning are not well exploited and utilization does not match the cost of their establishment. This can be due to a difficult location and overall formation of the classrooms.

- $\quad$ Pedagogical issues. Traditional textbooks do not require the use of CALL and are usually not flexible enough to integrate it as part of learning process. CALL sometimes seems to be an extra burden for teachers and learners.

- Socio-cultural issues. Some teachers refuse to annex CALL into their teaching, because the cultural influences might seem intimidating. For example, Fernando compares Sri Lankan higher education to Western education and states that "in many cases, e-learning cannot be implemented in the way it is done at US or European universities. The approach has to be tailored to the environment, if it is to be a success." $[18,2274]$ 
- Institutional issues. Successful integration depends on the objectives that institutions set and invest in. Level of administrative support for teachers is one of the many reasons to integrate CALL into teaching. The support has a notable role in implementing CALL. [19.]

Education has seen change of roles in teachers and students, as well as growth in learner autonomy, according to Hubbard. Still, it cannot be assumed that students have the necessary skills and strategies to use applications in the most effective way in their learning activities. An opportunity for self-study is not a definitive guarantee of autonomy. CALL does not eliminate the need for teachers, as learners do not readily accept personal responsibility for learning if no encouragement is received. The same aforementioned study conducted in the Middle East Technical University corroborate this claim, because it demonstrated that the students were highly teacher-dependent before they received training for creating effective learning strategies [16]. Facilitative teachers should pay more attention to how students use computers on their own and what type of content is the most beneficial to them [20, 14]. Student satisfaction can be a good substitute for user acceptance and is often used to measure students' attitudes in computer mediated learning $[13,1330]$.

\subsection{Challenges in student-centred environments}

While the higher education has arguably benefitted from student-centred approaches and e-learning, the pedagogy still has its challenges on various levels, for example in teaching, implementation process, technology utilization, maintenance and usage in different cultures.

From a pedagogical point of view, constructivism can be seen as a challenge for traditional teaching, as it has spawned an array of illusions and misconceptions among teaching and learning. One of the misconceptions is that the students can be left to one's own devices - readymade information should not be lectured, because students construct it themselves. Constructivism is not about "reinventing the wheel", but rather activating student's natural curiosity about the world; how the wheel turns and functions. An interesting humanistic view has occurred especially in vocational education - it highlights individual growth, self-direction and self-realization. Von Wright warns about the extreme forms of this kind of thinking by asking what the terms for rational self-regulation and selfdirectedness are. One of the key values for both teachers and students is to have a 
comprehensive understanding about the current teaching session and its goals. Teachers need to be aware of how students perceive new information and to know the frame of reference they are constructing it within. Also by knowing different learning strategies, student actions can be regulated accordingly. Essential for students is to know the main objectives of a given task and relevant questions at hand. [2.]

Issues in student-centred environments can also be found within the students themselves. Applying new processes in teaching can be initially met with resistance, as student-centred learning requires a different type of behavior from students. In countries with tuition fees, confronting the need to take more responsibility for learning, students may complain that they are paying the school to be taught and not teaching themselves. Cooperative learning tends to be one the hardest methods to be sold, especially for high performing students and strong introverts. Students may feel that they are being held back and slowed down by slower group members. Student-centred instruction can cause steep learning curves for both teachers and students. In the first phases of implementing student-centred approaches, course-end ratings may initially drop, which makes abandoning the new approach a tempting option for the teacher. [21, 43.]

Integrating technology to student-centred environments has its own challenges to overcome, such as teacher or organizational level incompetence and inexperience. Problems with technology are similar to the above discussed problems related to CALL; the most prevalent barriers to successful integration in student-centred e-classrooms are not just dependent on technological factors, but also organizational, political, cultural and psychological factors $[6,1596]$. Many teachers lack confidence in utilizing technology. Usually technology is used to present information, rather than giving practical activities to students. Some teachers are uncomfortable with investing instructional time to deal with the equipment and software, including their possible failures. Technology needs to support organization's current protocols, be part of organization-wide initiative and provide teachers an access to professional development and support. [22.]

A functional student-centred environment needs proper maintenance measures, as the need for regular reviews of assessment practices are the core of the approach. Organizational reflection needs to happen constantly in order for a student-centred learning environment to remain sustainable and effective. Negligence in maintenance has negative consequences, for example degeneration in information processing inside student groups. This manifests as decreased time used for self-study, inadequate preparations 
for presentations and an overall decrease in motivation and quest for learning. The institute's financial constrains show as inefficient student-teacher ratios and also contribute to the negative changes; increased amount of students in a study group can result in contracting advanced students to guide the groups. Lack of national funding and weak understanding of rudimental principles by teachers and students all contribute to the erosion of the doctrines, which makes student-centred environments work. [5, 52.]

There are also cultural difficulties to be addressed. Student-centered learning faces numerous problems in its implementation, especially in less developed countries. For example, in contrast to Western countries, the dispute surrounding teacher-centred and student-centred approaches is different in Central Asia. Only recently, teachers and students have been introduced to the debate between these approaches. The background for the discussion has been the rapid political, economic and social development and openness to Western values in some Central Asian countries. Sablonnière and others found out in their studies on the barriers to implementing student-centred learning in Kyrgyzstan that the problem is in surpassing an existing state of affairs; lack of normative structures in the country's education system has not enabled significant shift to happen towards student-centred approaches. [23.] 


\section{Trends in web-based learning}

\subsection{Technological and social advancements}

Higher education curricula are becoming more interactive and an increasing number of students are using mobile devices to access e-learning courses. Modern web technology can be used to create flexible services for educational use, containing versatile multimedia contents, such as animations, video, voice and augmented reality. As the current technologies enable faster wireless connections and applications require lesser processor and battery power from the end device, new opportunities for mobile oriented elearning, or m-learning has opened. In the short time period of the existence of smartphones, mobile technology has become one of the main mediums for content production. There is an increased demand for cross-platform compatible e-learning software. $[25,106$.

Mobile and web-based learning offers the ability to extend technology-mediated learning opportunities into new settings, but they are not only about shifting e-learning courses on a smartphone - they are about augmenting the learning performance. In e-learning platforms, more value is given to system modularity. Course material is based on smaller, singular learning modules, from which the students can pick the most interesting or relevant units to learn. In the advent of social media and the need for modular content, traditional learning management systems have been challenged by personalized learning environments (PLE), which allow users to utilize lightweight tools and services for individual and flexible use. These type of environments provide a variety of services and full user control. In practice, a PLE can be constructed from different social tools, such as blogs, wikis and RSS feeds. As these services are mostly the same people use in their workplaces or hobbies, they are easy to acquire. The tools of social media try to connect formal and out-of-class learning.

Cloud-based learning, or a cloud learning environment (CLE), is an extension to PLE. It is a learning facility enabled by services in the cloud. In this environment, the place of storage, or the "cloud", is described as a vast autonomous system, not in possession of any educational organizations and where the learners share the same privileges. Unlike in LMS platforms, where the focus is on the gathering of learning objects, a CLE supports composition of learning materials. Instead of point-to-point communication assessments, 
a CLE allows context-based communication and collaboration. This information can then be used and customized for personal purposes to meet an individual's own needs [34]. Although the tools of social media in education are undisputed, relying on old foundations and teaching methods might feel more secure to many institutions. Gathering these tools into a one ensemble can be challenging, due to their level of inconsistency, fragmentation and lack of privacy. [26.]

\subsection{Platform agnostic web}

The primary reason for e-learning industries shifting to new technologies and developing techniques is the massive use of mobile devices. Traditionally, dynamic and interactive learning content and especially video content for the web has been produced with Flash technology. As numerous mobile and desktop web browsers have been sequentially dropping support for Flash since 2010, HTML5 has strengthened its grip as the new industry standard as a means of content production. HTML5 is the newest version of the HTML-markup language, but typically the term refers to the combination of three technologies: HTML5, CSS3 and JavaScript. HTML5 has introduced a variety of attributes for rich application development, such as video and audio, "drag and drop" file upload, geolocation, touch events and 2D animations, all of which are nowadays widely supported by different web and mobile browsers [27]. Although HTML5 has not yet reached the same level of dynamism as Flash content, HTML5 made games and animations are constantly evolving and closing the gap of diversity between their Flash counterparts. [28.]

HTML5 can be described as a "platform agnostic" technology. As long as the users access an HTML application through a web browser, the application should perform seamlessly across different platforms, such as iPhones, Android phones, tablets and desktops. Although boasting a vast amount of different capabilities, HTML5-based applications still cannot compete with native applications, which are applications specifically built for a certain mobile platform. Given that native applications are integrated into the machine code, they have the ability to use device-specific hardware and software, such as a camera, GPS and multi-touch hand gestures. Native applications are generally achieving better performance results than their web-based alternatives. Movement towards device-agnostic mobile application is happening, but users of many learning environments are still struggling to use applications across different platforms [25, 354]. 
Although offering the tools for cross-platform development, pure HTML5 applications may not deliver the most ideal user experiences, for example if the system suffers from even the slightest bit of lag.

Hybrid mobile development might offer one solution for achieving the feel of native applications and easier development cycles, as hybrid applications enable HTML5 content to be embedded inside a mobile device's native platform container. The native container acts as a medium for the HTML application to communicate with the hardware of the mobile device. The HTML application can connect to the functions of the device, for example gyroscope and calendar, just like a native application would. Hybrid applications are distributed through digital distribution platforms, such as App Store and Google Play, where they can be downloaded. Figure 1 roughly demonstrates how web, native and hybrid applications communicate with the operating system and device.

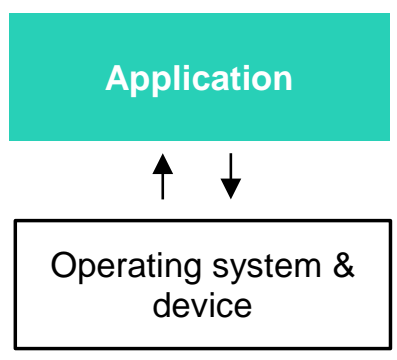

Native application

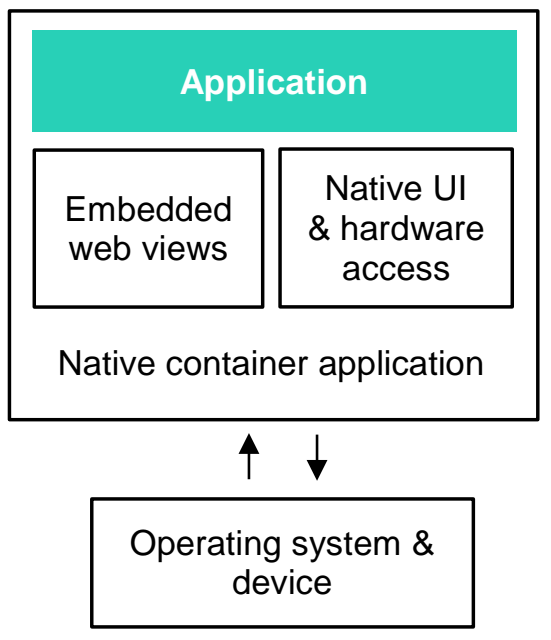

Hybrid application

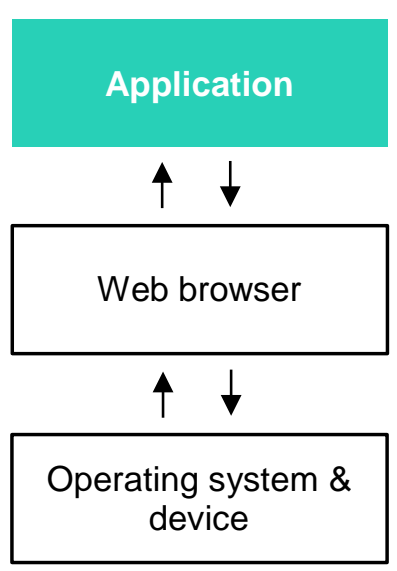

Web application

Figure 1. General overview of how applications function in different platforms. Copied from Globetrotter [29].

Developers do not need to learn native programming languages used on mobile devices, such as Java or Swift, in order to develop mobile applications, as they can reuse and apply their existing HTML5 knowledge. Using only one technology, development costs are greatly reduced as only a single version of the application is created. [29.] 


\subsection{Web 2.0 and language learning}

The current World Wide Web is referred as "Web 2.0", with the term being credited to and popularized by O'Reilly Media in 2005. Also referred to as "the social web", characteristics and typical services of Web 2.0 are social networking sites, media sharing, wikis and blogs, all of which give users a voice and encourage participation in content production. Anderson [31] found out distinguishable themes for the culture of the modern web, which in essence highlights individual production and user generated content, crowdsourcing information, ever-increasing amounts of data, openness and systems designed specifically for user contribution. Users are not just passively consuming the information, but can partake in generating it. Many Web 2.0 services annex different types of digital content together, producing "mashup" applications, where the idea is to generate new information by combining existing information. Given this sandbox nature of Web 2.0, it offers bounteous resources for language learners by shaping CALL to more versatile directions. [30, 30.]

Introduction of mobile devices has also initiated new naming conventions for CALL, as nowadays it is not just merely language learning aided by a computer. Jarvis argues that the acronym CALL is no longer valid term for understanding the field and should be referred as mobile assisted language use or MALU. Jarvis defines MALU as follows:

Non-native speakers using of a variety of mobile devices in order to access and communicate information on an anywhere/anytime basis for a range of social and academic purposes in second language learning.

The term would encompass all the features of CALL while recognizing the social uses in language learning, both in formal and less formal learning situations. [35.]

According to Zeng, many CALL practitioners believe that language learning is increasingly transforming in to an out-of-class activity [30,31]. Successful language learners make use of a wide range of learning methods outside the classroom, for example through cultural products such as movies and magazines. Web 2.0 readily offers the opportunity for accessing language learning resources - learners are interacting and collaborating internationally with tools like video, chat and different online gaming platforms. Zeng states that these out-of-class activities can support one of the current areas of research in the field of CALL: emerging online technologies to transform language learning. These social and interactive methods indicate that language learning is shifting 
focus from cognitive learning to more social direction and learners are encouraged to adopt these type of approaches and responsibility in their language learning. In this regard, participatory nature of Web 2.0 complements this current student-centred way of thinking in language learning. [30, 35-36.]

Crook established four central themes surrounding Web 2.0 applications in education, which are inquiry, collaboration, literacies and publication. These themes are different branches of student-centred learning and define a set of possibilities for the annexation of Web 2.0 services and features in educational practice. Their applicability for language learning can also be investigated [32]. One can also find similarities with Anderson's themes of the modern web.

Inquiry

Crook originally stated that Web 2.0 offers tools, which enable students to conduct personal research. In inquiry-based learning, students ask questions and gather data to support and refute hypotheses. Students apply and transfer knowledge in addition to just acquiring it. Software supports inquiry-based learning by facilitating storage and manipulation of large amounts of data. Different tools can help students to model phenomena and procedures for harvesting, organizing, visualizing and reviewing data. Inquiry-based software often enables students to create personal representation to express their own ideas [3, 301]. Inquiry-based learning assembles the paradigms of PLE and CLE by enabling learners to adopt a role of an explorer [34]. With the enriched learning resources and techniques that facilitate independent research, learning potential on the web and mobile can offer a sense of immersion for the studied language, as students do not physically need to be in the classroom, or even in the same country to interact with other people. [30, 42-44.]

\section{Literacies}

Cook described literacy as a new means of presentation and self-expression online and how Web 2.0 can support the new patterns of language learning [32]. For many teachers incorporating CALL in their teaching methods, multiple modes of self-expression have opened opportunities for student-initiated speaking assessments. Shang mentioned in her study about a teacher who required students to use podcasts for speaking practices outside of class, concluding that not only did technology provide opportunities for oral 
practice, but also a way to monitor the progress and performance of each student. Services, where user communications are video or text-oriented, like in Youtube and Vimeo, endorse the variety of self-expressive ways for authentic online language learning. [30, 40]

Publication

This theme ascends from the potential of Web 2.0 to support original content creation. Web 2.0 provides the tools, as well as the audience. Computer mediated content (CMC) traditionally supports text-based communication, which from language learning perspective helps students who have difficulties in listening comprehension by giving them time to think before responding. Wikipedia is argued to promote this conscious planning and interconnection of language learners, because it has a community for validating the content's formality and grammar. [30, 41]

\section{Collaboration}

As stated earlier, community building and user participation are one of the very characteristics of Web 2.0, the value of which Crook also highlights in education. This social part of the Web 2.0 is seen as one of the strong points for language learning as the networked communities can support it with collaborative efforts. Different services dedicated for this purpose, such as blogs and forums can be used for exchanging linguistic and cultural knowledge, for example through question-and-answer-based services like Stack Exchange. The questions and answers can be rated positively or negatively, depending on the question's difficulty, clarity and time used in individual research and relevancy of the answer. As the service is reputation-based, it can be a self-moderating system. [30, 38; 33]

Shang states that links between Web 2.0 and language learning can be established in accordance with Cook's taxonomy. Language learners are not only encouraged to practice their skills via computers, but also have the opportunity to receive and share information via social networks $[30,44]$. This statement is consistent with Jarvis' idea of MALU, which tries to capture all the learning processes and methods happening in formal and informal ways. Mobile assisted language learning seems also to compliment the principles of personalized learning environments. PLE appears as a cluster of Web 2.0 tools, which allow time and place independent learning. 


\subsection{Informal language learning}

Until very recently, technology has run parallel with other education theories, which are separate from technology, such as behaviorism, cognition and social cognition. Jarvis proposes a hypothesis, where education theory may no longer be separated from technology. Inadequacies in the theoretical models described above made Siemens suggest an idea of connectivism, which explains learning as a process of recognizing connections between information sources and as a meta skill for evaluating the worthiness of learning something. The theory supports student-centred learning and relies heavily on the informal part of it. [35.]

Informal learning is generally considered as learning happening outside an institution. Information construction and skill acquiring can occur through conversations and observations - it can be a situational, unconscious and a natural way of "picking up" information, such as hearing new vocabulary in the workplace. Jarvis discusses, how informal language learning applied to technology is a relatively new concept, because it takes the focus out of mere computer aided language learning in to a wider spectrum of mobile capabilities. As discussed earlier, Web 2.0 and CALL (or MALU) has enabled new informal ways of learning for example through blogs and social networks. Mobile learning has also brought back the behavioristic elements of CALL; common engagements for a mobile language learners include using chunks of their spare time for drill and practice, for example through listening practices and flashcards [25, 99]. Other uses include looking up vocabulary from an online dictionary in relevant contexts and interactions. These chunks of spare time might include daily commutes, breaks at work and other small gaps during the day.

Informal language learning has been recognized as an important tool for successful language learning. As a result, there has been an institution wide spark of interest in understanding how students create their own personalized learning experiences in mobile platforms. Jones discussed in her study, how informal mobile language learning can potentially overcome some of the challenges with minority languages and dispersion of speakers through virtual communities. Jones' findings among Welsh learners showed that listening was in the key role, while reading and writing were also core activities. Social tools, such as blogging and texting suggested that creating and reading short sentences can contribute to language learning and maintain language skills. Mobile devices supported spontaneous and planned learning, as students were actively switching between 
formal and informal learning [36]. Formal learning fits well for instructing beginners, who are learning completely new skills. Informal learning is accentuated in situations, where the missing piece of information is searched in order to activate previously known information to finish the current task. [37.]

\subsection{Existing platforms for language learning}

While the Web 2.0 offers a great variety of tools and resources to engage language practices, there are tailored services designed for the purpose. Appropriate application for the student depends on previous exposure to the target language, personal preferences and goals. Some students might require strict guidance and tutoring, while others can set their own milestones and act with greater autonomy. Considering the features of the application being developed in this thesis, this chapter introduces four services commonly used in Japanese learning, which support personal freedom, construction of knowledge and the informality of modern language learning.

Anki

Anki is a free flashcard program based on active recall testing and spaced repetition (SRS), available for both mobile and computer. The program displays a series of flashcards, contents of which can be for example vocabulary, where the students try to remember the correct translation and then continue to the next word. Users can choose whether they remember the answer easily or partially or whether they forgotten it completely. The program's algorithm then uses this user feedback to generate optimal intervals to show these specific cards again. Users can also create their own studying decks and share them in Anki's social portal, AnkiWeb, with other users. Anki supports HTML markup, which allows users to incorporate links, pictures and audio files with the flashcards. [38.]

Kanji Koohii

Kanji Koohii is a free web service specifically aimed for memorizing Chinese characters used in the Japanese writing system, in which over 2000 different characters see active use. Unlike in Anki, the service uses pre-existing flashcards, which are based on James 
Heisig's book "Remembering the Kanji", where recalling is grounded on the user's "imaginative memory" - an individual's own stories and associations of each character. Similar to Anki, the service uses SRS to display the cards, but is solely dedicated for memorizing the Chinese characters, with the aid of the user's own or community created stories. Creating a flashcard deck containing the same characters as in Kanji Koohii is possible in Anki as well, but the chances for community interaction and contributions in Kanji Koohii are better available. Kanji Koohii provides a forum for discussion and has a voting system for the community created mnemonics. [39.]

iTalki

iTalki is a language learning social network, which connects students, tutors and professional language teachers and aims to immerse students authentically to the target language. One of the main features of the service are private lessons. Users can pick a teacher or tutor of their choice, based on peer reviews and type of tuition offered, and take private language lessons on Skype or other video chat software at agreed time. The service has no tuition fees, but is paid by the lesson. Users can choose the topic they want to learn and the teacher will guide accordingly. The service also has a wide community base, where user created articles can be shared. Similar to Stack Exchange, the service has a question and answer area where language teachers and tutors correct user entries, accompanied by a voting system. [40.]

\section{FluentU}

FluentU is a monthly subscription-based mobile service which utilizes online videos as its main educational content. Although online videos are regarded as a traditional learning medium, FluentU is a good example of a service which makes a clever reuse of videos in an interactive context. For each language, FluentU has a collection of handpicked videos, for example related to TV shows, news and music videos. All the videos have interactive captions of the target language running parallel to the dialogue. Users can pause the video to look for more information about the word and see other uses of it through example sentences. Users can also take quizzes after watching the videos. [41.]

While these services cover only a fragment of the e-learning platforms available, they demonstrate the enormity of ways to approach language learning, which the Web 2.0 
and current mobile technologies enable. Immersion to the culture and language is one of the key values for successful language learning, which iTalki and FluentU can offer through 1-on-1 private lessons and interactive videos.

While Anki and Kanji Koohii do not have as interactive content as iTalki and FluentU, they support one other crucial aspect in language learning, which is constant repetition. According to Nakata, several studies have also suggested that flashcard learning is a valuable learning activity, because the vocabulary can eventually transfer to normal language use. [41; 42] 


\section{Designing the application}

\subsection{Different paradigms to consider}

In the context of mobile learning, there are a set of design issues related to pedagogical design. In the figure 2, Dennen and Hao present four different types of mobile applications, where each paradigm of application use has a primary relationship to particular student-centred learning theory. Each paradigm tends to draw upon and reflect dogmas and strategies of other theories as well, so the secondary relationships are visualized as dashed arrows.

$$
\begin{array}{cccc}
\begin{array}{c}
\text { Instructional } \\
\text { focus }
\end{array} & \begin{array}{c}
\text { Application } \\
\text { categories }
\end{array} & \begin{array}{c}
\text { Learning } \\
\text { theories }
\end{array} & \begin{array}{c}
\text { Design } \\
\text { principles }
\end{array}
\end{array}
$$

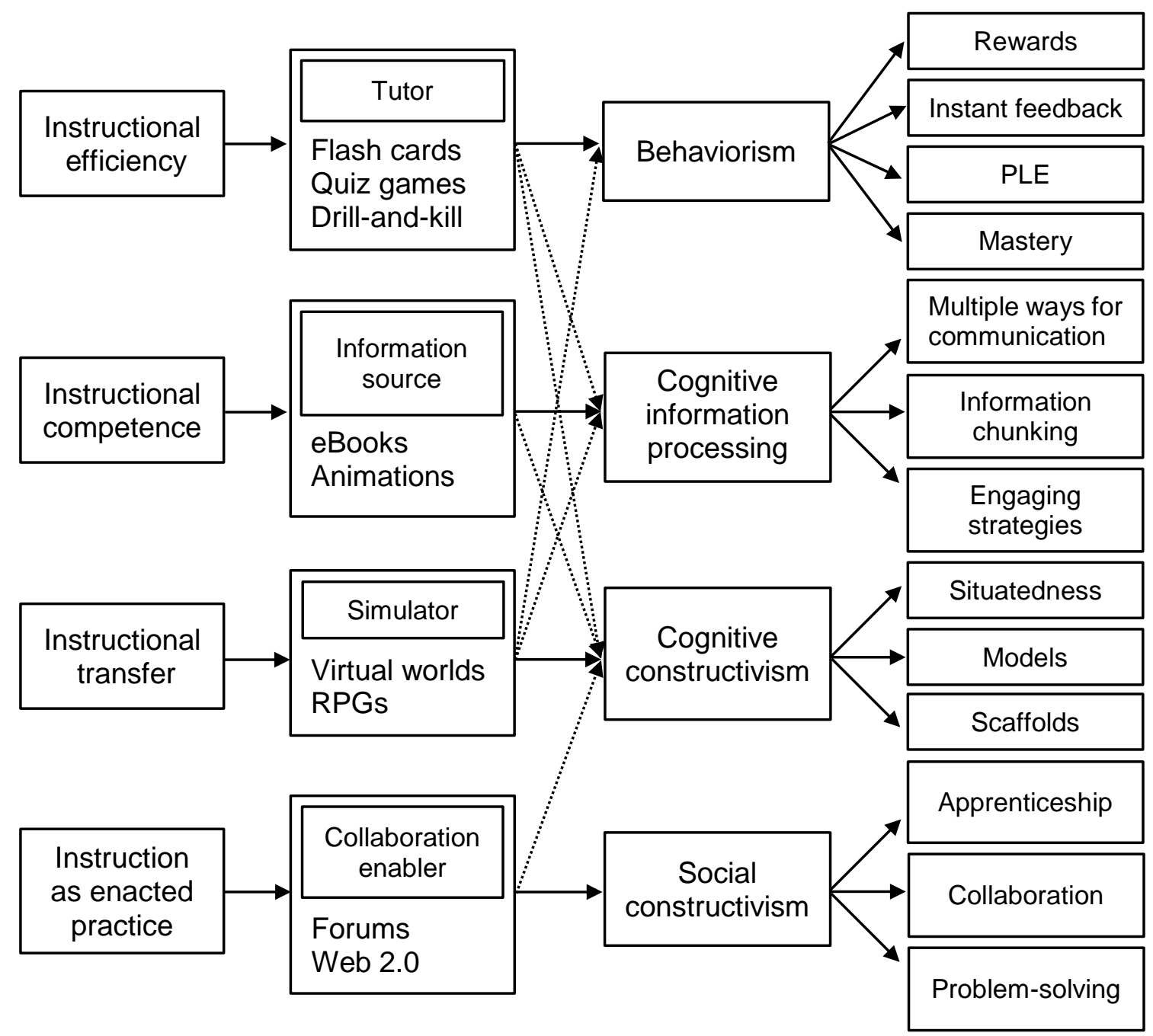

Figure 2. Relationship between paradigms and learning theories. [25, 28] 
Dennen and Hao believe that only one theoretical or pedagogical approach is not enough to meet the needs of modern mobile application-based learning.

Application as tutor

Applications fitting in the tutor paradigm rely heavily on behaviorist principles. Tutorbased learning is a continuous interaction between the learner and the human or computer-based tutor. The learner is usually presented with an explicitly defined task and the tools to complete it, while the tutor provides instant feedback by giving hints and corrections upon mistakes. These software usually have reward systems, which can be for example personal high scores, rankings or another type of achievements. Tutor-based applications are plentiful, partly because pedagogues and developers have understood that people want to use mobile devices to practice and review content, for example through spaced repetition software. While the concept of tutor-based applications may appear simple and the interaction merely template driven, inventive content and creative interaction design may help to attract learners more [25, 30]. As reminded by Yang and Jones (chapters 2.4 and 3.4), the same information given in multiple modes can further enhance the learning experience and captivate users.

Application as information source

Information sources do not support the entirety of the learning experience, but they provide the content, with which learners can create self-instructed strategies in order to gain knowledge. Other options can include using the application in facilitative ways by the teacher, or as a performance support by learners who are in a temporal need for knowledge and have no further intentions in acquiring the knowledge. Due to the nature of this paradigm, it is likely to combine with other design principles as well. Such a service could utilize a tutor-based element, an application where the information source is initially walked through by the learner, who would then have the opportunity to take a quiz and receive feedback. Notwithstanding the simplicity in interactive and adaptive features, these applications still take full advantage of mobile devices as a platform for distributing information directly in the situation in which it is used. With API calls, content can be fetched from external services, such as Wikipedia, to the situation where it is needed [25, 31-32]. Mashup applications commonly make multiple API calls to different services, in order to aggregate and combine information, while making the application as an information source more plenteous. 
Application as simulator

The core of a simulator application is in cognitive constructivism and learning occurs through a simulated environment. Role playing games and virtual worlds can offer visually pleasing environments to immerse and engage the learner, but they might initially require support when entering the simulated environment for the first time. Models, scaffolds and instructive feedback are more common in educational applications than ones developed for gaming or entertainment purposes. Models, like videos and animations, can be used to demonstrate the desired behaviour in the application. Organization tools, such as virtual coaches, task lists and environment maps can be used as scaffolds to direct learners to more constructive paths. Mobile-based simulation applications highlight the unique features of mobile devices, such as touchscreen, camera and geo-location and make use of augmented reality [25, 36]. While not explicitly educational, one of the archetypes of a simulator application is Pokemon Go. It encourages people to visit real world places in search of virtual items and creatures, but may also teach about geography of the neighborhood and help to develop mapping skills informally [43].

Application as collaboration enabler

Collaborative applications are closely aligned with social constructivism. Their ability to provide successful learning experiences are as dependent on the users and their desired tasks as application performance itself; independent and motivated students can compensate what the application may lack, but this can be a harder task for students with lower motivation. Collaboration enabled applications typically have learning content focusing on problem solving and usually offer a framework for group work, where students can discuss their ideas and contribute to their group's knowledge base with various mobile media supported formats. Any application which facilitates contribution to a webbased collaborative tool via mobile devices would qualify in this category. [25, 37]

\subsection{Towards the application}

Sendai National College of Technology has been renewing the schools' pedagogy over the last few years. Traditionally the education in the school has been teacher-centred, passive information transmission, but has been evolving and giving more focus on active learning, which is another adaption of student-centred approaches in teaching. Typical 
class activities include students engaging the material they study through reading, problem solving, group discussions and reflection while making use of technology. Switching the responsibility of learning to the students has also spawned an idea of a cross-platform application, which would support exchange students' Japanese language studies and endorse a self-driven way of learning.

The cognitive load that students experience during e-learning can be reduced by making use of collaborative learning $[12,1202]$. Thus, the main objective set to the application created in the final year project described in this thesis was to create a collaborative platform for student mediated learning contents, which would also allow students to comprise their own personal learning materials as well. The application is to offer a language learning environment, which puts the students in main role of content production, while the teacher would adopt a more facilitative tutoring role.

With these requirements in mind, the main student features were decided; the application would have a section where learning materials are created, a shared information bank for storing these learning contents collaboratively and student's own personal assignment section, where they can study the contents they have selected from the information bank. As teachers would also be a part of the environment, they have their own administrative view where they can answer student questions and an assignment creator for creating quizzes for the students.

In the original prototype model of the application, technologies selected for the development included MySQL and PHP, but upon my wish, technologies ultimately chosen were JavaScript-based frameworks, AngularJS and Firebase, as they provide a more modular base for creating modern, scalable and dynamic web applications with a potential for hybrid application development. Firebase also has properties that allow developing realtime features for collaborative applications [52].

\subsection{Main features of the application}

The goal for the web application is to offer exchange students an effective medium for informal learning - an environment where the students can input, view and study Japanese words and expressions in a way which encourages studies outside of exchange students' mandatory language learning classes. 
This section discusses how the main features of the application in development represent a particular pedagogical use and how they inherit characteristics of different pedagogical strategies described by Dennen and Hao in Figure 2.

\section{Word creation}

The learning contents are inputs of unknown Japanese words and expressions encountered by the students during their studies or free time, which they store in to the evergrowing database of words, or "word bank". The section, where the learning materials are created, has an HTML form with several input fields that describe the upcoming learning content, such as expression, translation and example sentences. When the necessary fields are filled, the student uploads the new word or expression in to the database by clicking a button. Making the students create their own materials through personal investigation and thinking, the application supports one of the student-centred elements - authentic learning through inquiry and exploration [3]. Creation process can also support cognitive constructivism, since it can have elements of situated learning; input can be done in the social situation in which it occurred or was heard. [25, 33.]

\section{Word bank}

Information containing all the learning materials is referred to as the word bank and it is the main place for collaboration. It provides an information source, where the students can search for specific words, inspect the words more closely and comprise personal learning materials. The word bank lists the learning materials as blocks one below the other, with each block displaying Japanese expressions and their corresponding translations. The word bank also allows deletion of an individual word.

\section{Single word page}

More detailed inspection of an individual word can be conducted in the single word page, which is entered from the word bank. The page displays all the other data the student had inputted during the content creation process, such as example sentences, tags and translations, which can be collaboratively edited. Besides just user-mediated data, the application makes use of external services in the single word page, which makes the application as an information source enhance the overall learning performance more profoundly by offering tools for temporal need for knowledge. The user has the ability to 
listen to the word pronunciation through a service called Forvo Pronunciation. Furthermore, the page utilizes a Kanji lookup feature through an electric dictionary, which displays more information about the Chinese characters individually if the word or expression contains any logographic Kanji characters. Decomposing of the word can facilitate information chunking, which is a design principle related to cognitive information processing $[25,28]$.

Assignments

Following the ideology of PLE, students should have the freedom to learn what they want and when they want. Students may choose the words they want to study from the word bank and then comprise them into learning packages for personal use. The main learning activity occurs in the assignment section, where the student's learning packages or "word decks" are stored. These word decks are studied as a set of flashcards, where the students have three options to study a chosen deck.

- Vocabulary memorization. The application quizzes the students, whether they remember the displayed word or not, until the end of the deck. Displayable words can either be set to appear in Japanese or translation first.

- $\quad$ Typing the word. This method is similar to vocabulary memorization, but the students have to write the correct translation to the input field.

- $\quad$ Listening comprehension. Words which have a corresponding Forvo pronunciation sound file available can be listened to and then typed in.

As reminded by Nakata [42], flashcard-based learning is an effective method for language learning, so the approach was used as a primary method for studying in the application. This feature makes the application act as a tutor, thus supporting the behaviorist learning theory, which is commonly applied in mobile learning [25, 99]. Students receive the correct answer instantly, if their input was incorrect.

Ask tutor

Outside of mere student collaborations, the application can enable two-way collaborations with teachers as well. This feature allows students to ask for help, seek ratification or inquire more information related to their learning materials, for example in making 
proper or additional translations, or in correct sentence formation. This direct link between students and teachers is a feature, which combines several design principles, such as instant feedback, multiple ways of communication and collaboration.

Teacher features

A further enhancement for the teacher-student collaboration enablement, the application provides an administrative view for the teacher. One of the main features for the teacher, besides just answering student questions and editing learning materials in the word bank, is creating different assignments and tests. The contents of these assignments are different than in student-created word decks - they can include for example multiple choice quizzes, particle or conjugation drills, which can be related to earlier classroom tuition. These teacher created assignments show up in the assignments section for every student.

\section{Recent activities \& notifications}

The main page contains a module, which keeps track of students' recent activities. Trackable activities are word additions, alterations and deletions made by the students and teachers. In addition, teacher created assignments get stored in to the module view as well. These events are also displayed inside the application through small notifications, each presenting information of corresponding action.

\subsection{Importance of usability}

Usability is a portrayal of user interface quality, which are defined by learnability, efficiency, memorability, user errors and user satisfaction, according to Nielsen [44]. In the context of e-learning, usability is about providing easy and efficient navigation to support students' goals of effective learning; it revolves around the idea of how to get students to interact and to be engaged with the system. Quality and effective engagement in elearning platforms has always been problematic and many e-learning applications suffer from high drop-out rates. Negligence in usability related matters can play a part in this non-completion of courses. As stated in chapter 2.2, usability related issues, such as difficult navigation can contribute to student's cognitive overload and make the individual 
leave the application. Due to the time and place independent nature of mobile applications, Nielsen's traditional usability measures used in normal websites may not be adequate in evaluating the usability of a modern e-learning system. Usability evaluation should be focused on processes that are supported by the e-learning system. [45.]

Several definitions around pedagogical usability have been established by different parties. The table below displays findings from two different studies. The first eight attributes presented are based on Zaharias' and Poylymenakou's usability factors in e-learning systems, which are leaning towards asynchronous (i.e. student-centred, autonomous) models of content delivery. Factors found by Horila et al. more or less correlate with Zaharias' and Poylymenakou's findings, but add two more distinctive attributes to the scheme - technical \& pedagogical threshold and added value for teaching. [46; 47]

These attributes are applied exclusively to the features where usability could potentially be evaluated in the application in development.

Table 1. Usability attributes based on Zaharias' and Poylymenakou's questionnaire and the findings of Horila et al. [46; 47]

\begin{tabular}{|l|l|l|}
\hline Usability attributes & \multicolumn{1}{|c|}{ Definition } & \multicolumn{1}{|c|}{ Possible applications } \\
\hline Content & $\begin{array}{l}\text { Language and terms used, } \\
\text { learning and supporting ma- } \\
\text { terials }\end{array}$ & $\begin{array}{l}\text { Layout is easily and intui- } \\
\text { tively understood }\end{array}$ \\
\hline Visual design & $\begin{array}{l}\text { Direct connection to delivery } \\
\text { of learning materials and aca- } \\
\text { demic discussions }\end{array}$ & $\begin{array}{l}\text { Aid from tutors, opportunities } \\
\text { for self-assessments, notifi- } \\
\text { cation messages, help centre }\end{array}$ \\
\hline Navigation & $\begin{array}{l}\text { Convenience and easiness to } \\
\text { understanding colour, font, } \\
\text { images }\end{array}$ & $\begin{array}{l}\text { Important elements are lo- } \\
\text { cated in places where they } \\
\text { most likely attract attention }\end{array}$ \\
\hline Accessibility & $\begin{array}{l}\text { Browsing activities and fea- } \\
\text { ture utilization }\end{array}$ & $\begin{array}{l}\text { Control of learning activities } \\
\text { and order of accessing } \\
\text { pages, locational awareness } \\
\text { in the application }\end{array}$ \\
\hline Interactivity & $\begin{array}{l}\text { Summarizes the access to } \\
\text { website pages and features }\end{array}$ & $\begin{array}{l}\text { Free from technical issues, } \\
\text { ubiquity in use, load time }\end{array}$ \\
\hline $\begin{array}{l}\text { All communication forms in } \\
\text { the learning context that are } \\
\text { facilitated by the system }\end{array}$ & $\begin{array}{l}\text { Range of information sources } \\
\text { (Kanji lookup, pronunciation } \\
\text { service), engaging and moti- } \\
\text { vating learning }\end{array}$ \\
\hline
\end{tabular}




\begin{tabular}{|l|l|l|}
\hline $\begin{array}{l}\text { Self-assessment \& } \\
\text { learnability }\end{array}$ & $\begin{array}{l}\text { Independent assessment as- } \\
\text { pects facilitated by the sys- } \\
\text { tem and capability of facilitat- } \\
\text { ing users on effective utiliza- } \\
\text { tion }\end{array}$ & $\begin{array}{l}\text { Adaption in creating content } \\
\text { without external advice, pre- } \\
\text { dictability of the result upon } \\
\text { clicking buttons }\end{array}$ \\
\hline Motivation to learn & $\begin{array}{l}\text { Ability of the system to sup- } \\
\text { port and engage motivation } \\
\text { to learn }\end{array}$ & $\begin{array}{l}\text { Enjoyability of collaboration } \\
\text { and creating personal learn- } \\
\text { ing materials, maintaining in- } \\
\text { terest in learning through its } \\
\text { different ways }\end{array}$ \\
\hline $\begin{array}{l}\text { Technical \& peda- } \\
\text { gogical threshold }\end{array}$ & $\begin{array}{l}\text { Types of technical and peda- } \\
\text { gogical prerequisites required } \\
\text { by the system }\end{array}$ & $\begin{array}{l}\text { How previous knowledge of } \\
\text { Japanese writing system and } \\
\text { grammar affect the learning } \\
\text { outcomes }\end{array}$ \\
\hline $\begin{array}{l}\text { Added value to } \\
\text { teaching }\end{array}$ & $\begin{array}{l}\text { Pros and cons of digital } \\
\text { learning content from teacher } \\
\text { perspective; connection in ef- } \\
\text { ficiency of learning }\end{array}$ & $\begin{array}{l}\text { Students and teachers recog- } \\
\text { nizing how the application } \\
\text { complements language stud- } \\
\text { ies outside of formal tuition. }\end{array}$ \\
\hline
\end{tabular}

The original questionnaire by Zaharias and Poylymenakou has seen previous usage in similar applications to that of one in development. The University of Indonesia used the questionnaire in a usability evaluation of student-centred e-learning environment [48]. 


\section{Technical execution}

\subsection{Architecture}

The application is built with AngularJS, which is a software framework used to deliver different views and all the other dynamic contents to the user. The database and storage are managed by Firebase, which is a "mobile backend as a service" (MBaas) provider that allows a way to link application data into a cloud storage. AngularJS exchanges data with Firebase through an application programming interface (API), which enables communication between various software components.

Providing cloud-based services and server-side processing, database and storage logic has been completely outsourced to Firebase. MBaaS takes away the need for developers to build their own database infrastructures, for example using server-side technologies such as Ruby or PHP. It also allows developers to concentrate on the front-end of the application, which users will see and interact with more. Developers can simply assemble the required building blocks needed for a specific function and write the code that connects them. MBaaS enables users to manage a centralized database, where content can be shared on the cloud. Figure 3 demonstrates the architectural model used in the application.

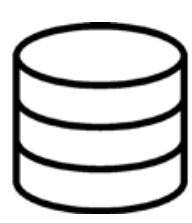

Server

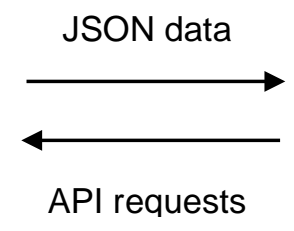

Browser

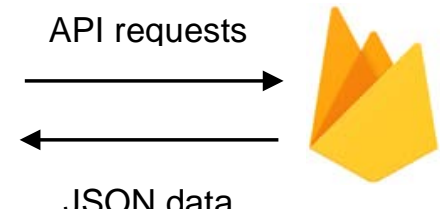

Firebase

Figure 3. Application's architectural pattern

This architecture is common for websites with a large codebase. It connects clients both to the server, where the actual application is hosted and Firebase, which hosts all the user data. Firebase offers real-time features, such as notifications without interfering with the rest of the application. [49.] 


\subsection{AngularJS}

AngularJS is a structural, Google maintained JavaScript-based framework for building dynamic, single-page web applications (SPA), which allow dynamic, rich and fast content delivery. It lets developers to use HTML as a template language and extend the HTML vocabulary to express different components of the application more clearly and succinctly. AngularJS applications are written in JavaScript, which is a high-level and dynamic programming language and one of the core technologies in web content production. Usually applications are not developed by just plain JavaScript, but with JavaScriptbased frameworks. By following the scripting standards set by the AngularJS framework and using the built-in services, developers can take advantage of such features as templating, filtering, data binding, dependency injections, all of which eliminate much of the code otherwise required to write [50]. For example, fetching the students' learning contents from Firebase and printing them in to the browser requires only a few lines of code.

With the perks listed above and built-in support of Ajax and REST-based application programming interfaces, AngularJS makes the HTML behave more like a desktop or mobile application by loading the content of a site within a single HTML page - once the main page is loaded, clicking on links does not reload the page, but simply updates sections in the page itself and loads only the content which is necessary at the time. As all this happens within the client's browser, AngularJS takes a lot of load time off from the server.

AngularJS was developed around three guiding principles: modularity, testability and maintainability. It aims to simplify web application development and testing by providing a client-side framework for the model-view-controller (MVC) architecture. MVC is a software architecture model, where different features of the application are broken into three separate components - the model which contains the data and logic, the view which contains the visual elements and presentation, while the controller is the part that receives instructions from the users. It also tells the view what to display and the model what to it should know at a given time. When the properties in the model get updated, so do the properties in the view. When the view gets updated, changes are propagated back to the model - this is referred to as two-way data binding. The controller is also responsible for all interactions with the database and other services which require API calls. Figure 4 on the next page describes how the system works. 


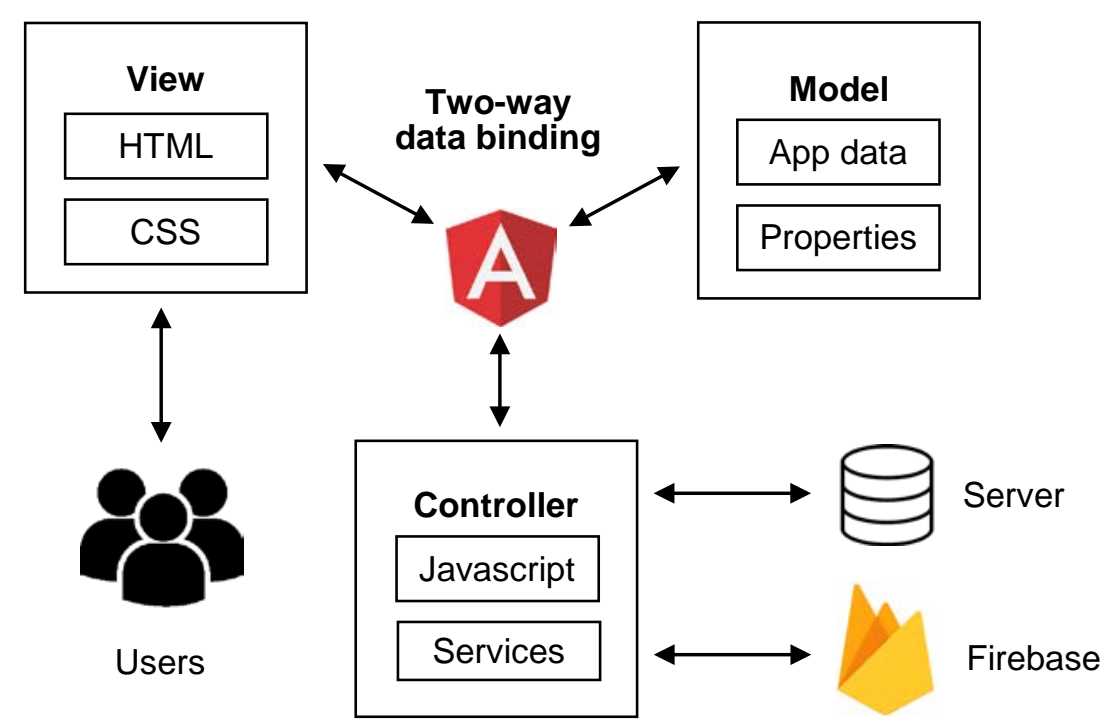

Figure 4. MVC architecture of AngularJS

One of the strong points of Angular is the capability of expanding the HTML vocabulary through directives; they allow creating HTML attributes with self-made behavior. These directives are valuable features in architecture modularity; it is a good practice to componentize the HTML structure if the content has a lot of repetition. Repetitive HTML content can be separated from its host template in to reusable components, which can be later called by their custom attribute names from within the host template.

AngularJS was built with the four basic functions of persistent storage in mind; creating, reading, updating and deleting (CRUD) data. While these properties represent the majority of web applications, AngularJS might not be the most ideal framework if the HTML structure or document object model (DOM) need to be heavily modified. Games and graphical user interface editors (GUI) are examples of applications that modify the DOM intensively.

Having a strong community behind the development, AngularJS has a vast variety of different community created third party modules, which are free JavaScript-based plugins that can be downloaded for individual use. These can be for example different CRUDbased modules, such as drag-and-drop file uploading.

There are currently two versions of the Angular framework, which see active use in web applications. However, naming conventions for the two versions can be distracting, as the framework versions 1.0 and higher are generally referred to as AngularJS, while the 
versions 2.0 and up are referred as just Angular. The second version of the Angular framework is a complete rewrite of AngularJS. It supports TypeScript markup, which is an object-oriented programming language maintained by Microsoft and is a superset of JavaScript. Version 1.5 of AngularJS was chosen as the framework for development, as it proved to have more comprehensive documentation, better community support and wider a variety of downloadable modules at the time being. The second version of Angular was officially released in September 2016 and version 4.0 was released in March 2017. These new Angular frameworks have no backwards compatibility with their predecessor, AngularJS. Due to the technological immaturities, Angular (version 2) was considered as a too abrupt choice for a framework, with which to develop the application.

\subsection{Data structures and bindings}

Data storing, server-side and front-end scripting is handled entirely with JavaScriptbased frameworks, plug-ins and libraries. As the design pattern follows MVC-architecture, the service is more robust and easier to maintain, because many developers are used to this way of programming. While AngularJS offers a good front-end framework for building a modular foundation for the application, web applications typically need a database to persist the application data. Traditional SQL-based relational databases are not very effective in terms of speed and performance, if the data is altered frequently. As the language learning materials to be created in the application would see a lot of collaborative additions, alterations and deletions, a NoSQL-based JSON database seemed as the most appropriate choice to deliver the back-end, as these kinds of databases can cope with vast amounts of simultaneous read-write operations by providing seamless horizontal scalability [51]. Firebase was chosen as the back-end, as it provides crossplatform support, real-time synchronization, offline persistence and good graphical user interface for administrative purposes. It also has special bindings for AngularJS to facilitate back-end scripting. As Firebase provides an ideal platform for creating collaborative software, it complies the student-centred attributes set for the application.

\section{Firebase}

Firebase is primarily a database that hosts application data, but changes occurring to that data are propagated in every device in real-time. For example, whenever the data is altered, all clients receive a notification within milliseconds. Besides just the database, 
Firebase also features a centralized data storage, third-party user authentication (for example through Facebook, Twitter and other social media accounts), analytics and crash reporting. While the free version of Firebase can offer all the above mentioned features, monthly paid subscription delivers more storage base, offers automated backups and hourly availability for Google Cloud Test Lab, which allows testing on physical mobile devices. [52.]

Unlike in MySQL, Firebase does not utilize table-like structure and relations in its database as it stores all data in a nested tree-like JSON-format. Upon creation, each new data node or tree branch generates its own unique key. The tree-like structure is demonstrated in the figure below.

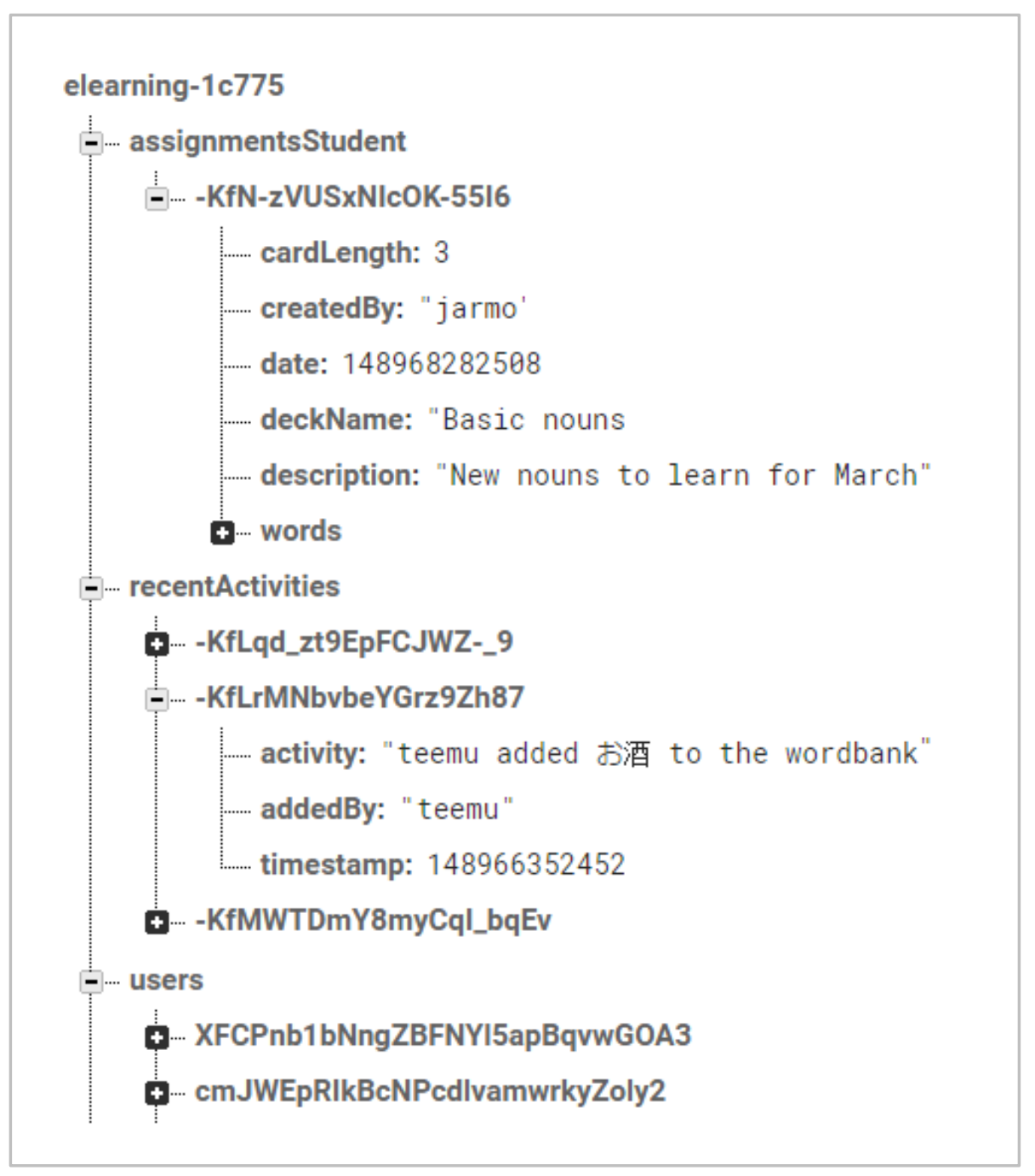

Figure 5. Example view from Firebase GUI, displaying the database structure. 
By using these unique reference keys in AngularJS scripts, different data nodes and their content can be accessed and viewed. Accessing the nested child elements require that the parent keys are also known.

The way of constructing a database differs greatly from SQL databases. For a developer with SQL background, some of the common practices used in NoSQL databases may even seem counter-intuitive. For example, data duplication is generally viewed as a bad practice in SQL tables, whereas in Firebase it is encouraged, since it fosters horizontal scaling. Effective data modeling in Firebase has a few precepts to follow, which are listed below.

- $\quad$ Shallow data structures. Firebase does not allow partial object pulling, so the whole object is pulled every time. This can be strenuous for Firebase, if it loads all the deeply nested nodes of unnecessary data from hundreds of users. In addition, someone with read or write access has a direct access to all data under these unwanted nodes. Dividing the data structures in to separate branches takes the load off from Firebase.

- Treating data as stream. When making queries to the database, it is not advisable to fetch collections of data upon every change that might occur to a singular data element, as Firebase will fetch the whole collection again. Fetching only the newly added elements promotes the philosophy of treating data as stream.

- Data duplication. As shallow data branches require additional queries, it is a good practice to duplicate data along with separated information. For example, user-mediated comment can have a duplicated username in the same object, so that it would not have to be separately fetched from other objects. Common data should be structured exactly how it is wanted to be read - data should look like the UI. [52.]

Common events in the application are word additions and the notifications that fire upon their submission or deletion, which is why they have their separate branches, as seen in figure 5. If the words and recent activities were under each user's own personal branch, every other piece of unnecessary user data would have to be pulled from the database as well. As there might be 5-10 active exchange students contributing to the database simultaneously, the amount of extra data to be pulled would start to put stress on the database.

Angularfire 
Firebase offers special bindings for AngularJS through a library called Angularfire, which helps in synchronizing Angular models to Firebase and supports user authentication and management. The library focuses in abstracting the standard scripts involved in creating AngularJS bindings to Firebase through different shortcuts, which shortens and simplifies normal AngularJS syntax greatly.

Just like AngularJS synchronizes the DOM with models in memory via the two-way data binding, AngularFire will synchronize the models in memory with Firebase - it extends the two-way synchronization between single clients to many clients. [53.]

\subsection{User interface implementation}

In accordance with MVC architecture, the user interface of the application is comprised of different views and partials. The views are HTML files, which obey different AngularJS bindings. These sub views are loaded in to the main view, creating the feel of a single page application - transition between pages happens through changes in the application's states. Views and their graphical contents are built with HTML5 techniques. Information fetched from external services provide their content to the user interface as well.

Routing and view nesting

Routing frameworks for single page applications update the browser's URL as the user navigates through the application, but they do not refresh the page at any point. URL routes programmatically present specific content to users, based on the URL that is currently displayed.

The application uses a module called UI-Router, which is a third party module and alternative routing mechanism for AngularJS applications. UI-Router has advantages over the default routing mechanism of AngularJS, primarily around the ability to decouple nested sub views. UI-Router enables displaying multiple views per template as well, each with their own data and controlling logic. This function is useful in larger applications where pages inherit information from other sections. The state tree is demonstrated in the next page. 
HTML document

- index.html

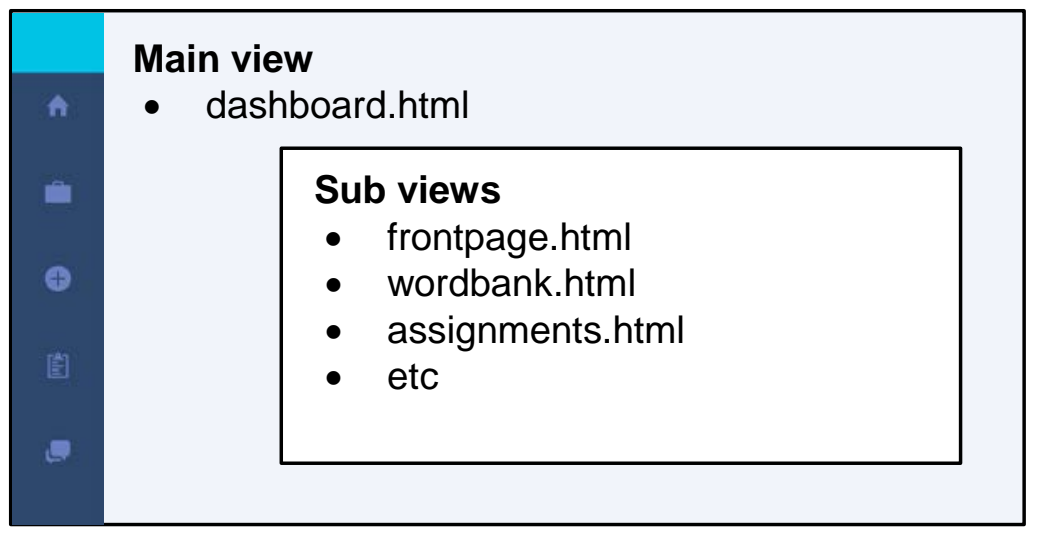

Figure 6. The state tree. Main view contains all the child views.

Views are loaded inside HTML content divs, which have a custom attribute called "uiview". The root page of the application, index.html, loads the main view inside the uiview-marked container div. The main view is always displayed. As displayed in the above figure, dashboard.html is the main view, which in turn loads all the sub views inside of its own ui-view container div. Every sub view page can be accessed by using the navigation bar, since it is always displayed.

Sub views are managed by the state function; when the user wants to go for example to the word bank, the application state is activated, the URL parameter gets updated and the sub view template is automatically inserted into the ui-view of its parent state's template.

URL routing used together with nested states makes these child states to append their URL at the end of their parent state's URL. Listing 1 in the next page demonstrates the relation of views inside the single HTML document used in the application. 


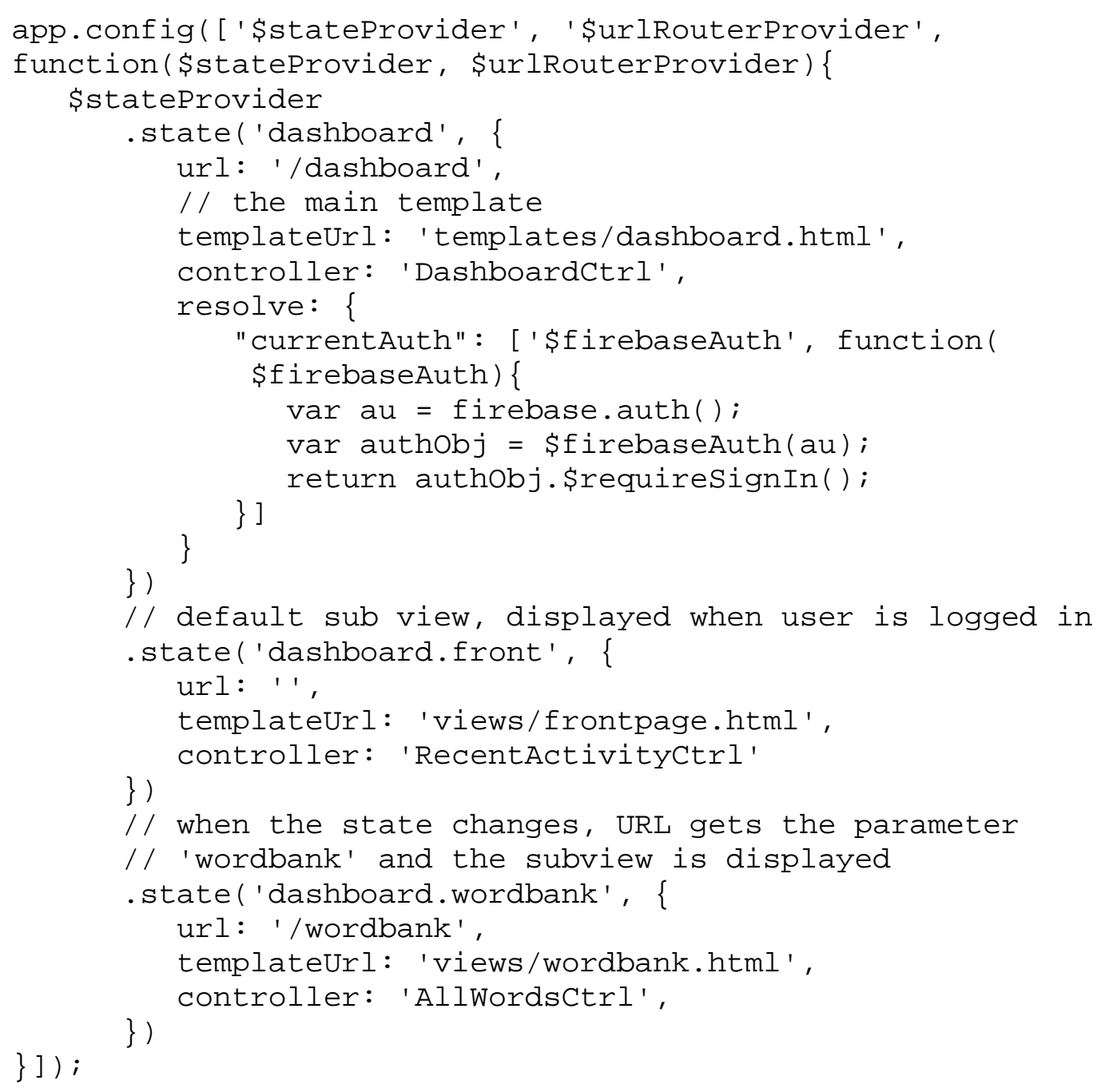

Listing 1. Routing configuration for the application.

The main view of the service has /dashboard at the end of its URL, but if the user goes to the word bank section, it changes to /dashboard/wordbank, creating the illusion of travelling inside folders.

The different child states are attached in to the buttons of the navigation bar in the main view, each of which correspond to specific sub view. The sub views are then loaded from the templates/views folder. [54.] 
Front-end

For creating the facades and overall visual look for the user interface, HTML5, CSS3 and other JavaScript-based technologies were used. For organizing HTML elements systematically suit both desktop and mobile devices, the application uses Bourbon Neat, which is a lightweight CSS-based grid system that aims to provide tools for instant utilization and adequate flexibility in grid customization.

Third party Angular modules were also used to enhance the user interface and user experience. Changes or possible errors occurring in Firebase needed to be visualized for users, so the application uses an Angular module called Toaster, which displays simple notifications in the upper right corner of the browser. The Angular module ngAnimate enabled the use of CSS-based animations and smooth transitions between pages. The last Angular module UI-Select was used to allow students to incorporate self-created tags with their words easily.

API calls

The application makes use of data that comes from external sources. AngularJS has a component for communicating, receiving and sharing data across controllers in a consistent and organized way through "services". Angular services are singletons, as all application components work with only one instance of it. They are also lazily instantiated, as AngularJS runs a service only when an application component depends on it. The application uses a built-in service called \$http in making connections to external web services, such as Firebase authentication, Kanji dictionary and Forvo Pronunciation, from where content is fetched on demand.

The Kanji dictionary is based on Jim Breen's electric dictionary [55], which is a free Japanese-English dictionary in machine-readable form. The dictionary has been stripped from unnecessary information and converted from the XML file format into the JSON format, which makes the file size more compressed and API calls easier in AngularJS.

The sound files are fetched via Forvo Pronunciation. It is a collaborative pronunciation dictionary that allows playback of sound clips in different languages. All the words are contributed by native speakers and stored in $\mathrm{mp} 3$ and Ogg format. 


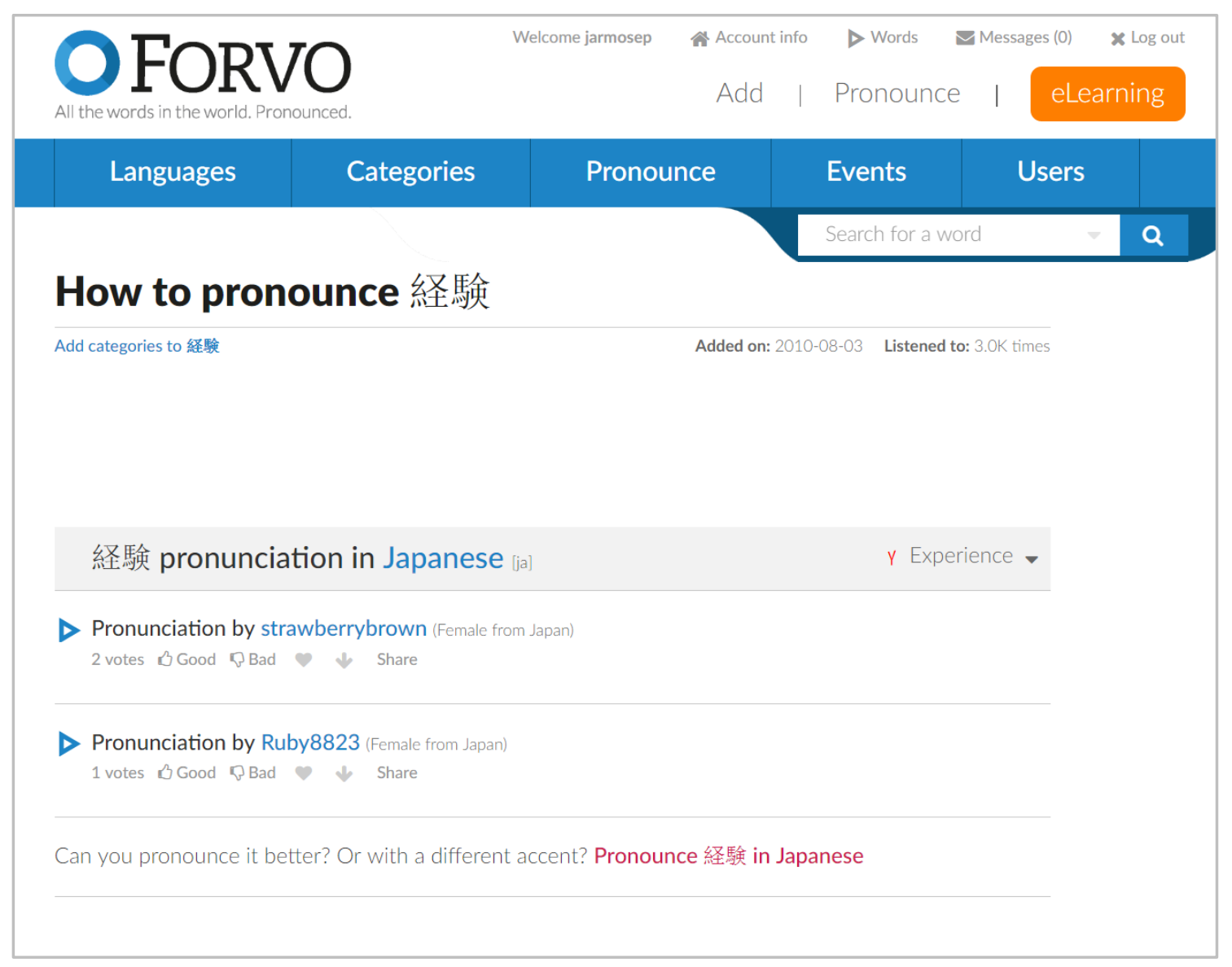

Figure 7. Searching word pronunciations in Forvo

Searching word pronunciations in the web service is free, but the use of its API has a monthly cost - non-profit monthly use allows 500 sound file requests per day, aiming it primarily for individual use. Forvo allows only one API key for the application and forbids the creation of multiple API keys for getting more daily requests.

As seen in figure 7, one word can have several pronunciations done by different individuals. As Forvo has a self-moderating voting system for the pronunciations, the highest ranking pronunciation gets always fetched first when making API calls. [56.] 


\section{Using the application}

\subsection{Profile configuration}

Before using the application, new students must create their personal user profiles. In the landing page, students are presented a registration form, which requires students to input their email address, desired username and password. This is demonstrated in figure 8 below.

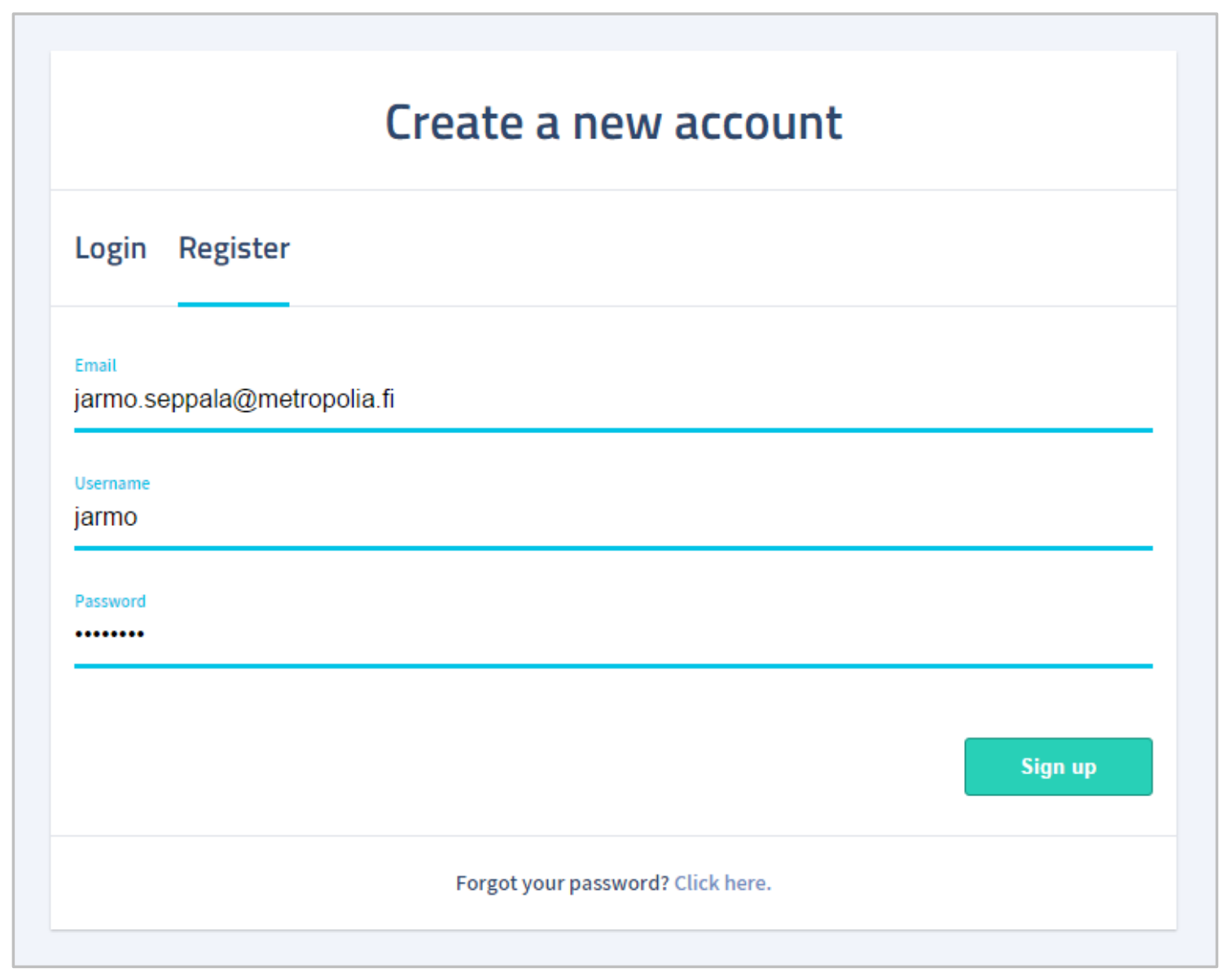

Figure 8. Landing page of the application.

Students can also edit their user profiles at a later time through a profile page, which is accessible from the top navigation bar. Only the username is permanent and cannot be changed. 


\subsection{Workflow of content creation}

From the very beginning of the development, the starting point for the application was to create a collaborative platform, where all the learning increments would be stored in one place and from where the students could choose the words they want to study. Word adding, word bank and assignments are key features of the application and they are displayed on the main page, which is shown in figure 9 below.

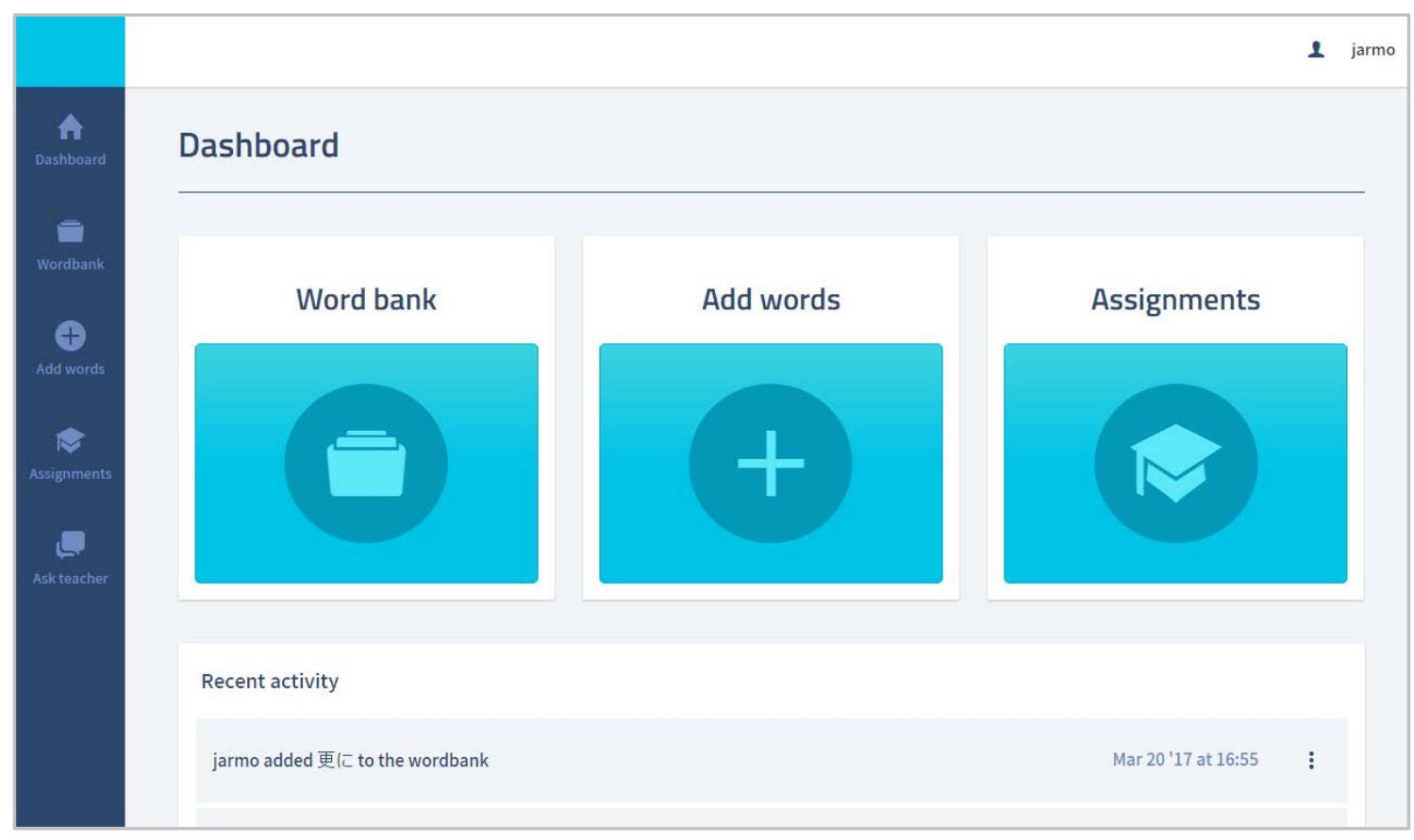

Figure 9. Main page of the application

The workflow of learning also consists of these three main features. The recent activity module lists all the tracked activities, such as additions, alterations and deletions in the word bank, as well as teacher mediated assignments.

Creating the materials - word adding

The learning experience starts from the learning material creation process. When the students have a word or expression they want to store in to the database, they navigate to the "Add words" section, where they are presented an HTML form. As the application is configured exclusively for Japanese learning, it takes in to account the two-sided writing systems of Japanese, which is a combination of logographic kanjis adopted from 
Chinese characters and syllabic kana scripts that are native to Japanese. Thus, the HTML form has the following input:

- $\quad$ Expression - written in Kanji, if the word is commonly or preferably written in Kanji letters. Otherwise written in syllabic kana letters.

- $\quad$ Reading - written in kana letters. They provide reading aid for the Kanjis letters by indicating their pronunciation. This field can be blank, if the expression does not have Kanjis.

- $\quad$ Meaning - direct translations, can be written in the user's native language.

- $\quad$ Tags - categorization system, which allows users to append default or their own tags to words. The application has 20 default tags, which are based on Jim Breen's abbreviations that are frequently used in dictionary entries [55].

- $\quad$ Sentences - allows students to create example sentences, which make use of the word or expression given in the first input field. Optional field.

The form can be seen in figure 10 below.

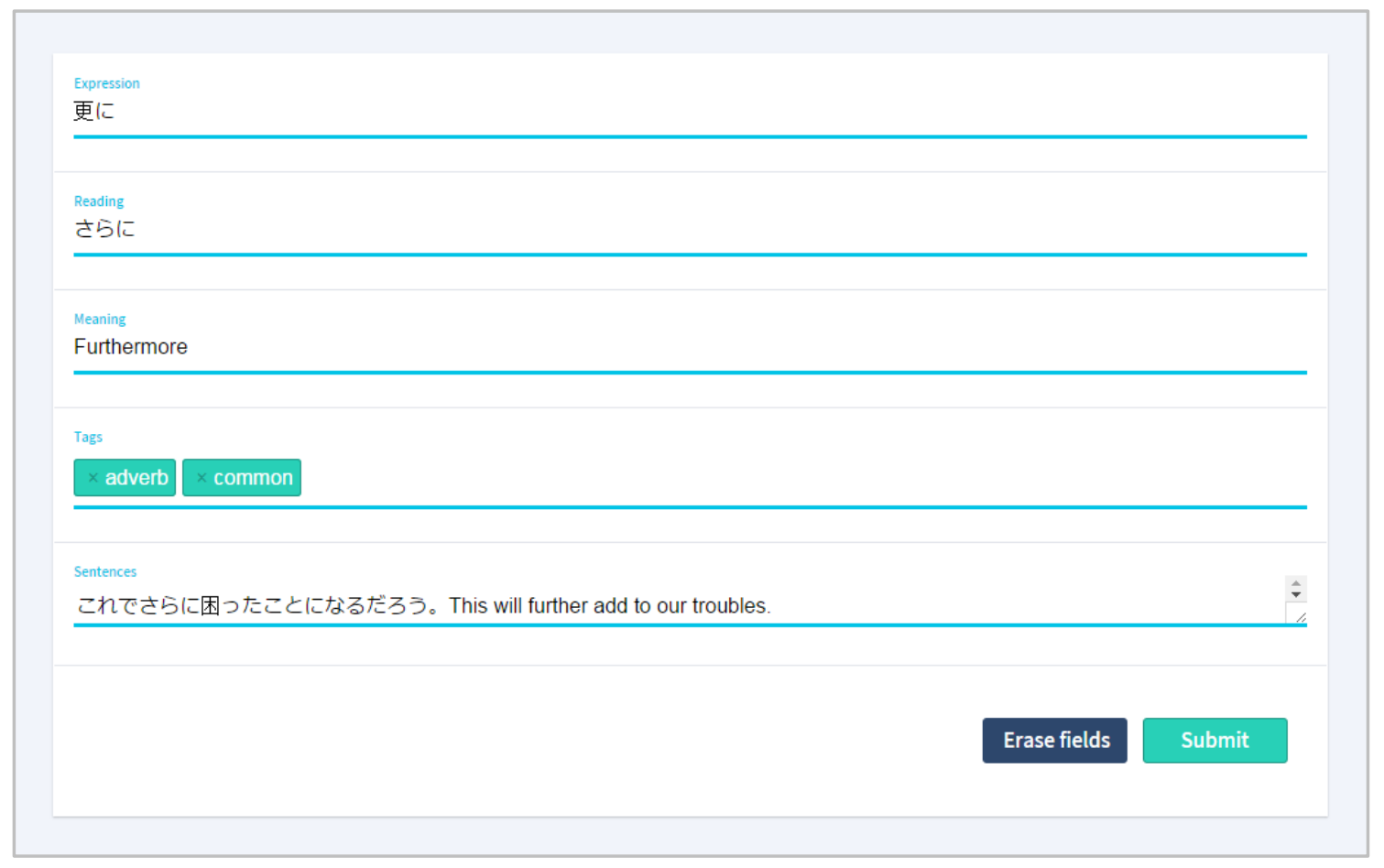

Figure 10. Word adding in progress

Students then fill in the required input fields, whether alone or with the help of other students, teacher or external dictionaries and then submit the entry. 
Viewing the materials

Viewing of the newly submitted content can be done in the word bank, and closer inspection is possible in the single word page. As demonstrated in figure 11, the word bank allows data filtering through tags, so the word can be sifted quickly among unwanted words through default or the student's own classifications.

Filters $\mathbf{V} \quad$ Create deck $\boldsymbol{}$

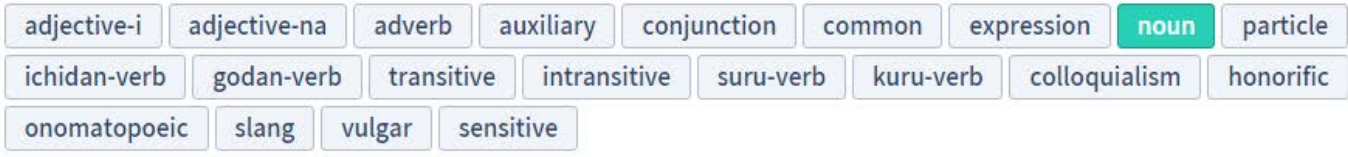

Figure 11. Word bank - searching the word with filters

When clicking an individual word, the application directs the user to single word page. On the next page, figure 12 demonstrates this single word page, which gives more information about the word. Usage of APIs can also be seen. 


\section{さらに}

\section{更に}

\section{Furthermore}

Example sentences

これでさらに困ったことになるだろう。This will furthermore add to our troubles.

Tags

adverb, common
Kanji

7 strokes. Grade 8.861 of 2500 most used kanji

grow late, night watch, sit up late,

of course, renew, renovate, again, more and more, further

On: コウ

Kun: さらさら.に ふ.ける ふ.かす

Figure 12. Single page view - displaying additional and API fetched information

All Kanji characters with their stroke amounts, commonness, English meanings and syllabic kana pronunciations are displayed. If available, pronunciation for the word can be listened to by clicking the white icon in the upper right corner.

Learning the materials

The final part of the learning workflow is comprised of creating personal word decks and learning them in the assignment section through a desired way of flashcard learning. The word deck is constructed in the word bank by enabling selection mode from the tool menu. Once enabled, all the words become selectable and can be simply clicked, in order to add them in to the student's study deck. When the students have completed selecting their materials, they click the "Create" button, which opens a modal window where they can give a name and description for their deck. Finally, students click the "Save" button to store the deck in to their personal possession. Figure 13 on the next page displays study decks created by an individual student. 


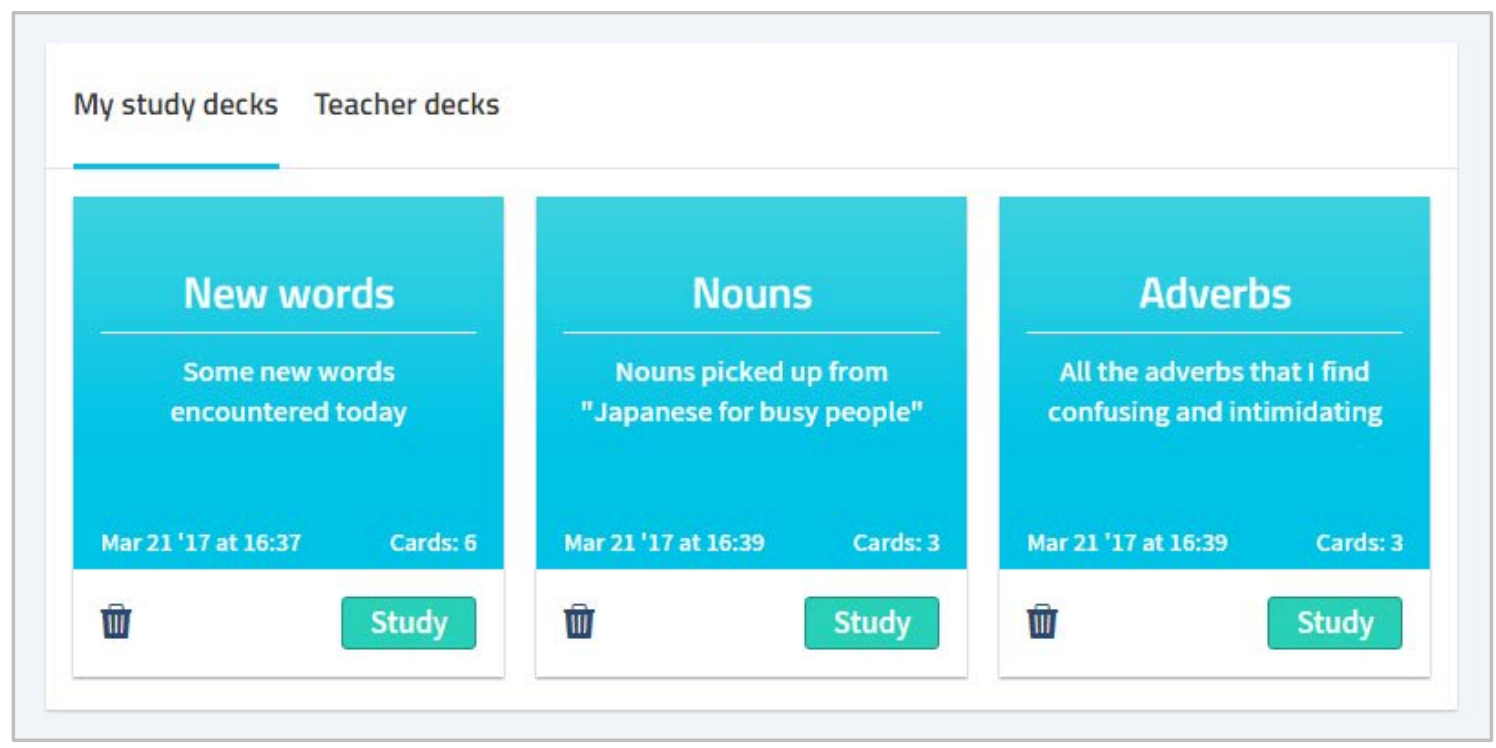

Figure 13. Student's personal study decks

When the student clicks "Study", a modal window opens and gives the option of memorizing, typing or listening to the words. The application then presents the flashcards.

Outside of the student-mediated learning materials, the teacher has the ability to create different types of assignments for the students and the ability to answer the student sent private questions. Teachers can inspect every student's questions, but individual students can only see their own. These features are demonstrated in figure 14 below and in figure 15 on the next page.

Answered (20) Unanswered (3)

jarmo asked: What is the correct use for the particle "さえ"?

Mar 22 ' 17 at 10:37

The particle "さえ" can mean "only", "even..." or "(did) not even". It can mean "even" sometimes, and "only" in other cases. When さえ is followed by a conditional, it means only. But when さえ is more of the main focus, it means even (and with a negative sentence, means 'not even').

Figure 14. Teacher answering a student question 


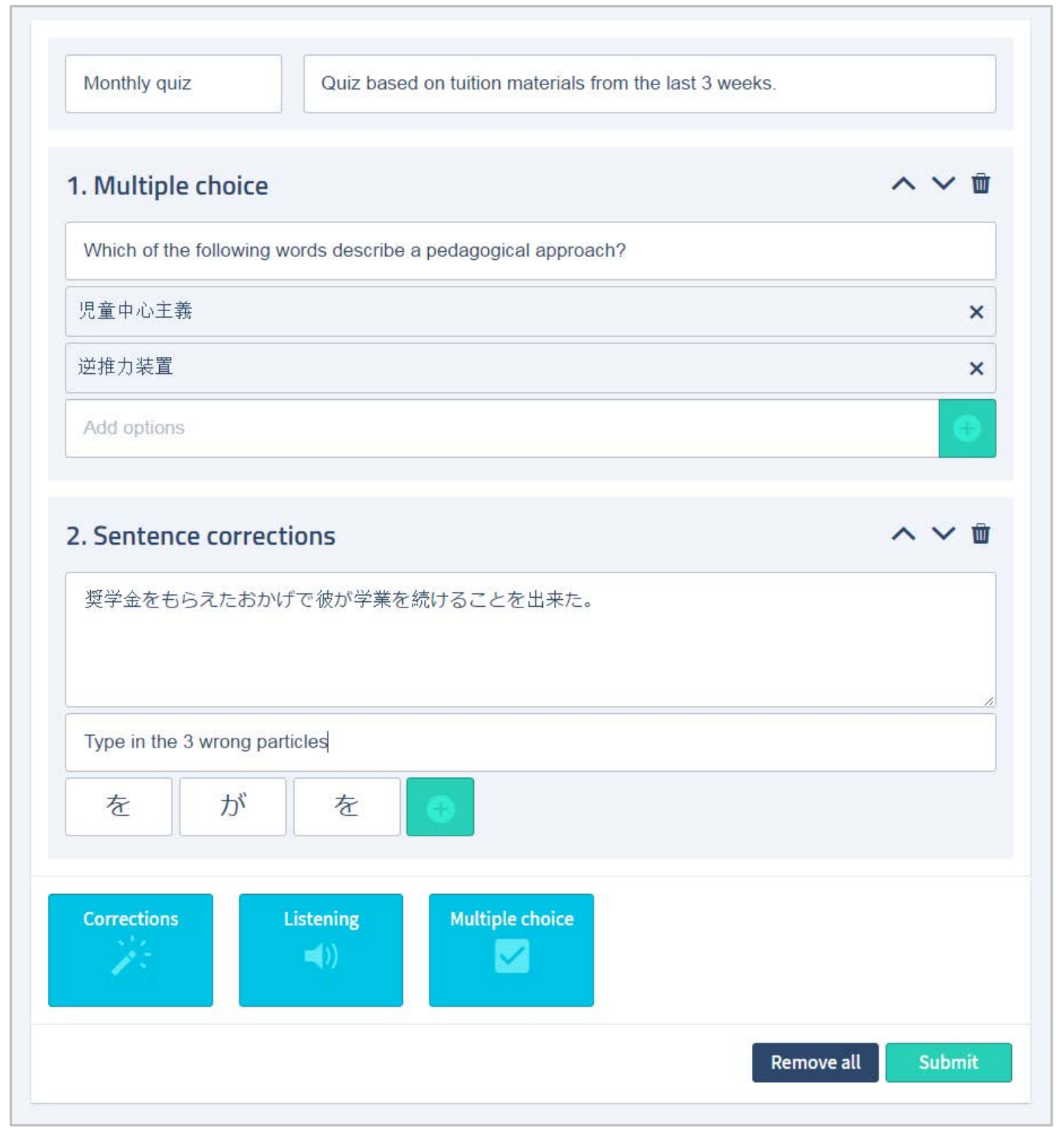

Figure 15. Quiz template - teacher creating a quiz

As implied in the above figure, the teacher can comprise a quiz sheet. The teacher starts creating the sheet by simply clicking the blue icons, which indicate specific assignments. The assignment then appears in the sheet, from where it can be configured to match educational goals. The position of these assignments can be adjusted by using the arrows in the right corner of each quiz increment. Currently, the assignment creator grants the teacher an option of creating only sentence corrections and multiple choice quizzes. 


\subsection{Analysis of the application}

The application is still in development. The main features are finished, but they still require further polish to achieve cohesive UI/UX experience. By analyzing all student-centred features of the application, the workflow of creating learning contents supports pedagogical elements of inquiry, collaboration and behaviorism in theory. Adding the scalability, as well as the time and place independent capabilities, the application meets some of the expectations that are set for modern mobile applications.

The application offers a future-proof and solid base for further development, as AngularJS-based applications will continue to see use in the near future as well. Firebase is a relatively new platform for delivering databases in the cloud and it does have some notable flaws. Firebase changed its syntax in its latest version 3.0, which made the previous documentation obsolete. The development of the application has been slow at times, because the current and official documentation is very tenuous. As Firebase is also constantly being developed, it is sometimes prone to minor bugs in some of its bindings.

As the application is aimed for experienced language learners and the target audience for the application consists of seasonal exchange students arriving in Sendai National College of Technology, the application requires specific types of users to conduct usability testing with. Thus, incremental usability evaluation in an authentic environment has not yet been conducted. Thus, further investigation of the application's effectiveness is in order, for example utilizing the questionnaire introduced in chapter 4.4.

\subsection{Future prospects}

Having established a few merits of the application in the previous chapter, the application offers a good modular base for further development and additional features. Future prospects can be investigated on feature, architecture and platform level.

The learning materials and example sentences in the word bank could be possibly made to have a self-moderating voting system similar to Stack Exchange or Kanji Koohii - it would also help in preventing inputs that are useless or too vulgar. Students' flashcard 
activities could incorporate spaced repetition algorithm to make studying a more scheduled process. Teacher mediated assignments could incorporate more behavioristic elements, such as scoring systems for the assignments. The application could also make use of Forvo Pronunciation API's upgraded monthly plan, which allows 10000 sound file requests per day and commercial use. An upgraded plan would provide enough queries for a small group of learners.

A much broader use of different Firebase features is also a worthy consideration. As Firebase offers several gigabytes of storage data, the application could utilize videos, audio files and images to accompany the learning materials. For example in the teacher's assignment creator - implementing listening practices through a video or an audio file could be a realistic possibility. Firebase also offers an event-centric analytics system, which can give teachers or administrators insight into what the students are doing in the application. This could also facilitate the maintenance of student-centred environments $[5,52]$, which was discussed in chapter 2.5 .

Although not a timely concern [57], an inevitable migration from Angular version 1 to version 2.0 or 4.0 will be conducted. Google will stop updating the original AngularJS framework, when the usage statistics for version 2 will exceed over 50\% in Angularbased websites. As this shift is happening relatively slowly on a global scale, AngularJS will serve as a viable framework to build upon for years to come. It is however unclear, if Angular 2.0 will take the dominant position among the Angular versions, as version 4.0 was released at the time of writing this thesis.

Building a hybrid mobile application that would be available on digital distribution platform, such as App Store or Google Play is a considerable option for attaining better user and learning experiences. A hybrid application would also bring new opportunities for building new features - students could for example use their mobile device's camera in order to store a memory rule for specific learning contents. Several open source frameworks that support Angular and TypeScript markup in building cross-platform applications already exist, such as Ionic, NativeScript and React Native. The last framework, React Native, takes a step even further in to the platform agnosticism. Due to its component-based structure, it can compile the HTML building blocks directly to native format without going through any container or simulative mediums as described in figure 1 in chapter 3, thus attaining the speed and functionalities that of native mobile applications. [58] 


\section{Conclusion}

Student-centred methods in both teaching and learning will continue to be a heavily utilized pedagogical strategy in higher education, at least in developed countries. Technology is an integrated part of the approach, where the Internet in particular plays a huge role - Web 2.0 and mobile devices bring tools which enrich the field and combine different pedagogies related to student-centred learning in new ways. Creative uses of student-centred learning go outside of traditional e-learning platforms, which usually tend to follow the formal means of education. Personalized learning environments bring in elements of social media and self-regulated studying to the learning process through mobile devices, therefore making learning a time and place independent activity. Supported by the studies used as references in this thesis, there seems to be a common consensus that much of the language learning today is conducted outside of tuition and it is also an encouraged practice. As Hubbard [59] stated, "technology is not just a support for learning: it is an integral part of the linguistic and cultural environment that we are preparing our students for."

The $21^{\text {st }}$ century teachers need to possess specialized proficiencies in many disciples to operate technically and to teach language or facilitate its learning efficiently. They also need to be evaluative and adaptive, in the sense of knowing the given technology's possibilities and limitations. Teachers need to prepare students for the reality of doing much of their language learning and interaction by informal and technological means. Achieving a successful student-centred e-environment requires effectively linking up pedagogy, technology and content, all this while keeping pace with new Internet technologies. Students need to be educated as well - it is a false assumption that students born in the era of digitalization can use technology for educational purposes naturally and efficiently.

I believe that the web technologies will have an even more important role in the future of e-learning, hence the big technological leaps in developing cross-platform applications. Modular and component-based frameworks are the future of web and mobile development. Hybrid application frameworks have come a long way in connecting the gap between high-performance native applications and easily developed web applications. From a software development point of view, I also believe that BaaS platforms will be the standard medium for developing back-end architectures for mobile applications in the near future. 
The growing trends of mobile learning and evolving web technologies influenced the frameworks and services ultimately chosen for the development of this final year project. Throughout the application implementation process, initially established objectives and desired features were followed carefully. Development is still in progress and the application needs further usability testing, preferably conducted with the exchange students of Sendai National College of Technology in Japan. Given the status quo, the current results attained in development can be considered a success, as the application provides all the originally designed features and a good foundation to continue the development. Future prospects include framework migration, creation of additional features and development of a hybrid application. 


\section{References}

1 Nordic Council of Minister's ad hoc group for quality in higher education. Studentcentred approach from Nordic Perspective [online]. Norden; 11 November 2017. URL: https://karvi.fi/app/uploads/2016/06/Ad-hoc-group-for-quality-in-HE_finalreport_2015.pdf. Accessed 30 January 2017.

2 Pekkalin, Sinikka. Opettajakeskeisyydestä opiskelijaläheisyyteen [online]. ePeda; 22 August 2006.

URL: http://elearn.ncp.fi/materiaali/epeda/verkkojulkaisu/yleinen/materiaali/Opettajakeskeis_opiskelijalahtois_220806.pdf. Accessed 2 February 2017.

3 Woolf, Beverly. Building Intelligent Interactive Tutors: Student-centered strategies for revolutionizing e-learning. Massachusetts: Morgan Kaufmann Publishers; 2009.

4 Rogers, C. R. \& Freiberg, H. J. Freedom to Learn, 3rd edition. Columbus: Charles E. Merrill Publishing Co; 1994.

5 Attard, A., Di lorio, E., Geven, K. \& Santa, R. Student-centred learning - toolkit for students, staff and higher education institutions [online].

Education International \& The European Students' Union; October 2010.

URL: http://www.aic.Iv/bolona/2010/Reports/SCL_toolkit_ESU_EI.pdf.

Accessed 7 February 2017.

6 MCCombs, B. \& Vakili, D. A Learner-Centered Framework for E-Learning [serial online] 2005;107(8):1582-1600.

URL: https://pdfs.semanticscholar.org/c4c7/b2278c96b467cf7e84a058d3c46b8 27e81ee.pdf. Accessed 7 February 2017.

7 Rosenberg, Marc J. E-Learning: Strategies for Delivering Knowledge in the Digital Age. Blacklick, Oklahoma: McGraw-Hill Professional Publishing; 2000.

8 Allen, E. \& Seaman, J. Online Report Card - Tracking Online Education in the United States [online]. Babson Survey Research Group \& Quahoq Research Group; February 2016.

URL: http://onlinelearningsurvey.com/reports/onlinereportcard.pdf. Accessed 11 February 2017.

9 Koli, H. \& Silander, P. Verkko-opettajan työkalupakki - oppimisaihiosta oppimisprosessiin. Helsinki: Finn Lectura; 2003.

10 Salavuo, Miikka. eOppimista vai suorittamista ja dokumentinhallintaa? [online]. Miikka Salasvuo; 6 April 2011.

URL: http://miikkasalavuo.fi/2011/04/06/eoppimista-vai-suorittamista-ja-dokumentinhallintaa. Accessed 13 February 2017. 
11 LMS/LCMS Functionality Guide [online]. District Reform Support Network; 2014. URL: https://rttd.grads360.org/services/PDCService.svc/GetPDCDocumentFile?fileld=4426. Accessed 13 February 2017.

12 van Mierlo, C., Jarodzka, H. \& Kirschner, P. Cognitive load theory in e-learning. [serial online] 2012;1:1183-1202.

URL: https://www.researchgate.net/profile/Paul_Kirschner/publication/286292232_Cognitive_load_theory_in_e-learning/links/ 566bd02108aea0892c4d8ā6f/Cögnitive-load-theory-in-e-learning.pdf. Accessed 15 February 2017.

13 Chen, Y., Yeh, R., Lou, S. \& Lin, Y. What Drives a Successful Web-based Language Learning Environment? An Empirical Investigation of the Critical Factors Influencing College Students' Learning Satisfaction [serial online] 2013;103: 3271336.

URL: http://dx.doi.org/10.1016/j.sbspro.2013.10.463.

Accessed 15 February 2017.

14 Hubbard, Phillip. An Invitation to CALL - Foundations of Computer-Assisted Language Learning [online]. Stanford, California: Stanford University; 14 January 2016.

URL: http://web.stanford.edu/ efs/callcourse2/CALL1.htm.

Accessed 16 February 2017.

15 Yang, Youwen. Computer-assisted Foreign Language Teaching: Theory and Practice [serial online] 2010;1(6):909-912.

URL: http://dx.doi.org/10.4304/jltr.1.6.909-912. Accessed 19 February 2017.

16 Mutlu, A. \& Eröz-Tuğa. The Role of Computer-Assisted Language Learning (CALL) in Promoting Learner Autonomy [serial online] 2013;51(4):107-122. URL: http://www.academypublication.com/issues/past/jtr/vol01/06/25.pdf. Accessed 19 February 2017.

17 Bax, Stephen. CALL - past, present and future [online]. Kent, England: Canterbury Christ Church University College; 28 June 2002.

URL: http://www.u.arizona.edu/ jonrein/internettech10/bax_03.pdf. Accessed 19 February 2017.

18 Fernando, S. Issues of e-learning in third world countries. Encyclopedia of information science and technology. IGI Global; 2009.

19 Hassan, M. Issues of Computer Assisted Language Learning Normalization in EFL Contexts [serial online] 2013;5(1):193-194.

URL: http://dx.doi.org/10.5296/ijl.v5i1.3305. Accessed 20 February 2017.

20 Hubbard, Phillip. Computer Assisted Language Learning: Vol 1 (Critical Concepts in Linguistics). London: Routledge; 2009. 
21 Felder, R. \& Brent, R. Navigating the Bumpy Road to Student-Centered Instruction [serial online] 1996;44:43-47.

URL: http://www4.ncsu.edu/unity/lockers/users/f/felder/public/Papers/Resist.html. Accessed 20 February 2017.

22 Moeller B., \& Reitzes T. Integrating technology with student-centered learning [online]. Quincy, MA: Nellie Mae Education Foundation; June 2011.

URL: http://ltd.edc.org/sites/ltd.edc.org/files/Integrating-Technology-with-StudentCentered-Learning.pdf. Accessed 20 February 2017.

23 de la Sablonniere, R., et al. Challenges of applying a student-centered approach to learning in the context of education in Kyrgyzstan [serial online] 2009;29(6):628-634.

URL: https://www.researchgate.net/publication/223743592_Challenges_of_applying_a_student-centered_approach_to_learning_in_the_context_of_education_in_Kyrgyzstan. Accessed 18 February 2017.

24 Shore, Amanda. LMS Systems Need To Be Student-Centered and Mobile [online]. The OOHLALA Blog; 18 February 2016.

URL: http://blog.oohlalamobile.com/2016/02/lms-systems-need-to-be-studentcentered-and-mobile. Accessed 20 February 2017.

25 Miller, C. \& Doering A. The New Landspace of Mobile Learning - Redesigning Education in an App-Based World. New York: Routledge; 2014.

26 Olander, Ilkka. Kohti henkilökohtaisia oppimisympäristöjä [online]. Sometek; 15 January 2012.

URL: http://sometek.fi/kohti-henkilokohtaisia-oppimisymparistoja. Accessed 22 February 2017.

27 Deveria, Alexis. Can I use [online]. 22 February 2017.

URL: http://caniuse.com. Accessed 22 February 2017.

28 Flash vs HTML [online]. Waste Creative.

URL: http://flashvhtml.com. Accessed 22 February 2017.

29 Hybrid Applications And Android Native Browser [online]. Globetrotter; 15 April 2014.

URL: https://myshadesofgray.wordpress.com/2014/04/15/hybrid-applicationsand-android-native-browser. Accessed 23 February 2017.

30 Zeng, Shuang. English learning with Web 2.0 - An investigation into Chinese undergraduates' technology (non)use and perspectives [graduation thesis]. IOE EPrints. London, England: UCL Institute of Education; February 2015. URL: http://eprints.ioe.ac.uk/21822/. Accessed 23 February 2017.

31 Anderson, Paul. What is Web 2.0? Ideas, technologies and implications for education [online]. JISC Technology and Standards Watch; February 2007. 
URL: http://www.jisc.ac.uk/media/documents/techwatch/tsw0701b.pdf. Accessed 23 February 2017.

32 Crook, Charles. Web 2.0 technologies for learning: The current landscape - opportunities, challenges and tensions [online]. Becta. Nottingham, England: University of Nottingham; May 2008.

URL: http://dera.ioe.ac.uk/1474/1/becta_2008_web2_currentlandscape_litrev.pdf. Accessed 24 February 2017.

33 Japanese Stack Exchange [online]. Stack Exchange.

URL: http://japanese.stackexchange.com/help. Accessed 24 February 2017.

34 Mikroyannidis, A., Okada, A., Correa, A. \& Scott, P. Inquiry-Based Learning on the Cloud. In: Chao, Lee ed. Handbook of Research on Cloud-Based STEM Education for Improved Learning Outcomes. Hershey PA, USA: Information Science Reference; 2016. p.291-310.

35 Jarvis, H \& Achilleos, M. From Computer Assisted Language Learning (CALL) to Mobile Assisted Language use (MALU) [serial online] 2013;16(4):1-18.

URL: http://files.eric.ed.gov/fulltext/EJ1004355.pdf. Accessed 24 February 2017.

36 Jones, Ann. Mobile Informal Language Learning: Exploring Welsh Learners' Practices. The Open University; 2015. eLearning Papers (45), article no. 6. URL: http://oro.open.ac.uk/44908/1/Mobile\%20informal\%20language\%20learning\%20eLearning\%20paper.pdf. Accessed 24 February 2017.

37 Informal learning: Extending the impact of enterprise ideas and information [online]. Adobe Systems Incorporated; 2007.

URL: http://www.clarix.com/whitepapers/informal_learning.pdf.

Accessed 25 February 2017.

38 Anki 2.0 User Manual [online]. AnkiWeb.

URL: https://apps.ankiweb.net/docs/manual.html. Accessed 26 February 2017.

39 Kanji Koohii - Learn more [online]. Kanji Koohii.

URL: http://kanji.koohii.com. Accessed 26 February 2017.

40 About iTalki [online]. iTalki HK Limited.

URL: https://www.italki.com/about. Accessed 26 February 2017.

41 FluentU - About Us [online]. FluentFlix Limited.

URL: http://www.fluentu.com/about. Accessed 26 February 2017.

42 Nakata, Tatsuya. Computer-assisted second language vocabulary learning in a paired-associate paradigm: a critical investigation of flashcard software [serial online] 2011;24(1):17-38. 
URL: https://www.researchgate.net/publication/254217121_Computer-assisted_second_language_vocabulary_learning_in_a_paired-associate_paradigm_A_critical_investigation_of_flashcard_software. Accessed 26 February 2017.

43 Learning with Pokémon Go [online]. National Geographic Kids.

URL: http://kids.nationalgeographic.com/family/learning-with-pokemon-go. Accessed 1 March 2017.

44 Nielsen, Jacob. Usability 101: Introduction to Usability [online]. Nielsen Norman Group; 4 January 2012.

URL: https://www.nngroup.com/articles/usability-101-introduction-to-usability. Accessed 3 March 2017.

45 Sharma, S., Chen, R. \& Zhang J. Examining Usability of E-learning Systems - An Exploratory Study [serial online] 2014;81:120-122.

URL: http://www.ipedr.com/vol81/019-ICERI2014-R10003.pdf. Accessed 3 March 2017.

46 Pedagoginen käytettävyys [online]. Jyväskylä, Finland: University of Jyväskylä; 18 June 2010.

URL: https://koppa.jyu.fi/avoimet/mit/virtuaaliset-oppimisympaeristoet/oppimisympaeristoejen-kaeytettaevyys/pedagoginen-kaeytettaevyys.

Accessed 3 March 2017.

47 Zaharias, P. \& Poylymenakou, A. Developing a Usability Evaluation Method for eLearning Applications: Beyond Functional Usability [serial online] 2009;25(1):7598.

URL: https://www.dmst.aueb.gr/Documents/PhD/Phd_thesis/Zaharias.pdf. Accessed 3 March 2017.

48 Junus, I., Santoso H., Isal R. \& Utomo A. Usability Evaluation of the Student Centered e-Learning Environment [serial online] 2015;16(4):62-82.

URL: http://www.irrodl.org/index.php/irrodl/article/viewFile/2175/3491.

Accessed 4 March 2017.

49 Goodrich, Ryan. What is BaaS (Backend as a Service)? [online]. Business News Daily; 26 August 2013.

URL: http://www.businessnewsdaily.com/4992-what-is-baas.html.

Accessed 5 March 2017.

50 AngularJS API Docs [online]. Google.

URL: https://docs.angularjs.org/api. Accessed 5 March 2017.

51 Peltola, Marko. NoSQL-tietokannat tieteellisen tutkimusaineiston arkistoinnissa [online]. University of Jyväskylä; 17 March 2011.

URL: http://users.jyu.fi/ maanpelt/graduseminaari_peltola.pdf.

Accessed 5 March 2017. 
52 Firebase documentation [online]. Google.

URL: https://firebase.google.com/docs. Accessed 6 March 2017.

53 AngularFire documentation [online]. Firebase.

URL: https://www.firebase.com/docs/web/libraries/angular/api.html.

Accessed 6 March 2017.

54 Mržljak, Goran. Ul-Router - In-Depth Guide [online]. GitHub; 28 November 2016.

URL: https://github.com/angular-ui/ui-router/wiki. Accessed 6 March 2017.

55 Breen, Jim. KANJIDIC2 home page [online]. Electronic Dictionary Research and Development Group; May 2012.

URL: http://www.edrdg.org/kanjidic/kanjd2index.html. Accessed 7 March 2017.

56 Forvo API Plans \& Pricing [online]. Forvo.

URL: https://api.forvo.com/plans-and-pricing. Accessed 7 March 2017.

57 Usage statistics and market share of AngularJS for websites [online]. W3Techs; 2017.

URL: https://w3techs.com/technologies/details/js-angularjs/all/all.

Accessed 7 March 2017.

58 Wodehouse, Carey. 7 Reasons Why Facebook's React Native Is the Future of Hybrid App Development [online]. Upwork; 13 January 2016.

URL: https://www.upwork.com/hiring/mobile/react-native-hybrid-app-development. Accessed 13 March 2017.

59 Hubbard, Phillip. English Teaching in the Year 2032 [online]. TESOL Connections; 1 May 2012.

URL: http://newsmanager.commpartners.com/tesolc/issues/2012-05-01/3.html. Accessed 13 March 2017. 